FEDERAL RESERVE

BANK of

RESEARCH DIVISION Working Paper Series

ST. LOUIS

\title{
How Does the FOMC Learn About Economic Revolutions? Evidence from the New Economy Era, 1994-2001
}

\author{
Richard G. Anderson \\ and \\ Kevin L. Kliesen \\ Working Paper 2011-041A \\ https://doi.org/10.20955/wp.2011.041
}

December 2011

FEDERAL RESERVE BANK OF ST. LOUIS

Research Division

P.O. Box 442

St. Louis, MO 63166

The views expressed are those of the individual authors and do not necessarily reflect official positions of the Federal Reserve Bank of St. Louis, the Federal Reserve System, or the Board of Governors.

Federal Reserve Bank of St. Louis Working Papers are preliminary materials circulated to stimulate discussion and critical comment. References in publications to Federal Reserve Bank of St. Louis Working Papers (other than an acknowledgment that the writer has had access to unpublished material) should be cleared with the author or authors. 


\title{
How Does the FOMC Learn About Economic Revolutions? Evidence from the New Economy Era, 1994-2001
}

\author{
Richard G. Anderson* \\ Kevin L. Kliesen** \\ *Research Division \\ **Supervision and Regulation Division \\ Federal Reserve Bank of St. Louis
}

\begin{abstract}
Forecasting is a daunting challenge for business economists and policymakers, often made more difficult by pervasive uncertainty. No such uncertainty is more difficult than projecting the reaction of policymakers to major shifts in the economy. We explore the process by which the FOMC came to recognize, and react to, the productivity acceleration of the 1990s. Initial impressions were formed importantly by anecdotal evidence. Then, policymakers - and chiefly Alan Greenspan - came to mistrust the data and the forecasts. Eventually, revisions to published data confirmed initial impressions. Our main conclusion is that the productivity-driven positive supply side shocks of the 1990s were initially viewed favorably. However, over time they came to be viewed as posing a threat to the economy, chiefly through unsustainable increases in aggregate demand growth that threatened to increase inflation pressures. Perhaps nothing so complicates business planning and forecasting as policymakers who initially embrace an unanticipated shift and, later, come to abhor the same shift.
\end{abstract}

Key Words: FOMC, productivity, learning, financial crisis

JEL Codes: D70, D71, E52, E58

** Kliesen: kliesen@stls.frb.org (corresponding author)

* Anderson: anderson@stls.frb.org

Views expressed are our own and not necessarily those of the Federal Reserve Bank of St. Louis, the Board of Governors of the Federal Reserve System, nor our friends and colleagues. We thank Charles Gascon, Michael Cassidy, Tom Pollman, Giang Ho, Aeimit Lakdawala, Marcella Williams, and Linpeng Zheng for research assistance. 
Monetary history reveals the fact that folly has frequently been paramount; for it describes many fateful mistakes. On the other hand, it would be too much to say that mankind has learned nothing from these mistakes.

Knut Wicksell (1935, p.4), as cited by Meltzer (2003, p. 725).

For monetary policymakers, and for business economists, a major challenge is tracking, understanding, and recognizing changes in the economy as they occur. Economists are fond of modeling economies as mathematical systems but some policymakers-former Fed Chairman Alan Greenspan, perhaps most notably — emphasized that model uncertainty causes monetary policy to be an exercise in risk management. In this framework, policymakers seek to learn about the changing economy even while they adopt policies that hedge against large unfortunate outcomes not well captured by the forecasting models. ${ }^{1}$ To a large extent, the Greenspan paradigm was an exercise in policymaking under both risk and Knightian uncertainty. In a world characterized by Knightian uncertainty, the probability distribution of outcomes following economic shocks are not readily known to the policymaker ex ante. By contrast, under conventional measures of risk, policymakers have some ex ante knowledge of the distribution of outcomes. In Greenspan's view, therefore, policymakers are rarely sure of which probability distribution they are confronting. Thus, the prudent course of action is an application of Bayesian decision making: (i) gather as much information as possible; (ii) quantify the probability of possible outcomes; and, (iii) act aggressively to hedge against potentially catastrophic outcomes (deflation or depression).

During the so-called "New Economy Era," labor productivity (output per hour) played a key role in shaping the Federal Open Market Committee's (FOMC) response to evolving economic conditions. Indeed, productivity discussions have a long history at FOMC meetings. For instance, unexpectedly strong productivity growth during the early 1980s generated arguments that would become familiar to participants more than a decade later. Questions such as: How much should the Committee risk its price stability goal to gamble that nascent accelerations in productivity will persist? If the Committee were to regard the risk as unacceptable and tighten policy preemptively—as suggested by inflation forecast targeting with models that do not incorporate the positive shock to productivity growth-how much

${ }^{1}$ See Greenspan (2004). 
output is lost? And, how does this interact with the FOMC's dual mandate from the Congress to seek both price stability and maximum sustainable economic growth? Policymakers and their staffs do use models, of course, explicit and implicit, and such models may be false in ways that impair their usefulness.

In this article, we thus examine how monetary policymakers recognized and responded to the productivity acceleration of the 1990s. We focus specifically on why, initially, they regarded the acceleration as positive (a rightward shift in the textbook "aggregate supply" curve), but later came to regard the sustained acceleration as a threat to inflation stability (a rightward shift in the "aggregate demand" curve). We seek clues that illuminate how members of the Federal Open Market Committee (FOMC) struggled to balance huge information flows that were sometimes contradictory with their forecasts and their ex-ante views of the monetary transmission mechanism over the medium term. By drawing from Verbatim FOMC meeting transcripts, we will show how Greenspan nearly single-handedly convinced the FOMC that the economy was changing in ways that the data and the models could not conceive of in real time. ${ }^{2}$ We do not ask whether the Committee's decisions were consistent with any specific macroeconomic model. Instead, we focus on the evolution of the dynamic process consisting of interaction among the economy, the Committee's members, and the FOMC's staff. ${ }^{3}$ At times, we include rather long quotations from the transcripts. In our opinion, these are valuable to understanding the issues, and do not indicate a lazy unwillingness on the part of the authors to summarize the argument. ${ }^{4}$ Verbatim

2 To track the evolution of FOMC thinking regarding changes in trend, or structural, productivity, we quote extensively from publicly available transcripts of FOMC meetings. In some cases, we have lightly edited the transcript to reduce length and enhance readability. The original transcripts are available on the Federal Reserve Board's web site. Comparisons between our quotes and those transcripts are easily made via simple text searches. ${ }^{3}$ Although we refer to the "FOMC staff," these are the staff of the Federal Reserve Board of Governors. All FOMC briefing materials available to the public are materials produced by the Federal Reserve Board staff, in two parts. These are commonly are referred to by the cover of their covers as the "Greenbook" and "Bluebook." Additional, ad hoc materials also may be distributed. These materials become public five years after the respective FOMC meetings after redaction of certain material. In addition, materials are prepared for Reserve Bank presidents by their staffs. So far as we are aware, these materials are not circulated to other FOMC members nor are archived to be made available to the public. Romer and Romer (2008) compare the accuracy of forecasts produced by Board staff to those of FOMC members, including the Reserve Bank presidents. The latter do not fare well in the comparison. ${ }^{4}$ This paper is an extension of Anderson and Kliesen (2010), which examines the evolution of FOMC thinking regarding changes in trend, or structural, productivity from the 1980s to 2007. They also quote extensively from publicly available transcripts of FOMC meetings. Federal Reserve staff input to the FOMC consists of two parts. First, the Board of Governors staff prepares material in advance of each meeting. These materials often are referred to by the color of their covers as the "Greenbook" and "Bluebook." Beginning in 2010, the Greenbook was expanded 
meeting transcripts are released by no other central bank in the world, and furnish a unique opportunity to understand the dynamics of monetary policymaking.

\section{A BRIEF REVIEW OF THE DATA}

During the last decade or so, a consensus has arisen among economists that trend growth rates for potential real output and labor productivity increased around 1995. Figure 1 shows that that the acceleration in productivity, as measured over different horizons, appeared to occur in the mid-1990s. Because the 1990s acceleration of labor productivity was unforeseen and challenged extant views, its recognition was delayed. Typical is the 1996 Economic Report of the President, prepared during 1995. In the report, the Council of Economic Advisers projected that labor productivity in the private nonfarm business sector would increase at an average annual rate of 1.2 percent from the third quarter of 1995 to the end of 2002. This estimate extrapolated recent experience: from 1973 to 1995 productivity had grown at an average annual rate of 1.4 percent. Initial productivity measurements published during 1995 and 1996 were consistent with the Council's forecast, and did not signal an increase in productivity growth

\section{[Insert Figure 1]}

The incoming data during 1995 and 1996 clashed with widespread anecdotal firm-level evidence that spending on information and communication technology equipment was increasing productivity. To some analysts, the productivity acceleration was no more than a cyclical response to more robust economic activity. But, at the same time, large investments in information and communication technology (ICT) equipment could not be ignored. ${ }^{5}$ Analysts quickly identified decreases in semiconductor prices, and the prices of business equipment built with them, as the primary cause of the productivity acceleration. But, prices also had fallen in the past—would rapid price decreases be

to include more analysis of financial market conditions, and renamed the "Tealbook." Additional, ad hoc materials also may be prepared and distributed. Federal Reserve Bank staff also prepare materials for each Bank president. Forecasts and most other briefing materials prepared by the Board staff become public five years after the respective FOMC meeting, although some portions are redacted from public documents. Materials prepared by Federal Reserve Bank staff are not made public.

5 Such changes are not confined to the United States. See Pilat and Lee (2001) and Colecchia and Schreyer (2002) for a survey the OECD countries. Armstrong et al. (2002) examine the Canadian experience. 
sustained? Further, some analysts asked if the increased investment in ICT was largely a change in the type of producers' durable equipment being purchased, rather than a genuine capital deepening. A typical after-the-fact assessment is Jorgenson, Ho and Stiroh (2002): “. .. the story begins with an increase in total factor productivity growth in the IT-producing sectors (computer hardware, software, and telecommunications), which led to falling relative prices and induced capital deepening in IT equipment."

By 2001, the Council of Economic Advisors had increased its projection of the annual growth of structural labor productivity to 2.3 percent per year. Indeed, the 2001 recession dispelled doubt regarding the staying power of the productivity acceleration. During the recession, productivity growth defied historical experience by increasing rather than decreasing. ${ }^{6}$ Other forecasters, including many included in Blue Chip Economic Indicators and the Federal Reserve Bank of Philadelphia's Survey of Professional Forecasters (SPF), were even more optimistic. ${ }^{7}$ As seen in Figure 2, private-sector forecasters surveyed for the SPF since 1992 did not increase their estimate of structural productivity growth until 2000, when they raised their estimate from 1.5 percent to around 2.5 percent.

[Insert Figure 2]

\section{LEARNING, THE CANONICAL MODEL, AND THE GREENSPAN MODEL}

Learning is an essential part of modern macroeconomics and essential to our narrative. The literature regarding learning in macroeconomic models is large and growing. In one significant contribution, Thomas Sargent (2008) notes the distinction between outside learning in which an observer seeks to gain understanding of the economy's workings, and inside learning where the actions of the learners themselves alter the path of the economy. Almost every history of the Federal Reserve System can be interpreted as containing some element of learning by policymakers. Allan Meltzer's (2003)

\footnotetext{
${ }^{6}$ See the discussion in Edge, Laubach and Williams (2004). Interested readers also should compare Gordon (2000) and Gordon (2003). In his earlier writings, Gordon argued that productivity had not accelerated in nearly 90 percent of the economy and that trend growth of total factor productivity had actually decelerated. The passage of time, and revisions to the data, have confirmed the shift in trend. The evidence for potential GDP remains mixed, however; see for example Kouparitsas (2005).

${ }^{7}$ See the Sept. 10, 2000, Blue Chip Economic Indicators or the First Quarter 2001 Survey of Professional Forecasters.
} 
extraordinary history of the Federal Reserve, in part, is a history of learning how to conduct monetary policy. ${ }^{8}$ In a similar vein, portions of Milton Friedman and Anna Schwartz's monumental monetary history of the United States explore the evolution of monetary policymaking thinking at the Federal Reserve after 1913; see especially section 3 of chapter 6 (pp. 249-270) and the discussion of policymaking during the Great Contraction in chapters 7 and 8.

The closest antecedent to our work is Romer and Romer (2002), which explores the FOMC's (and the Council of Economic Advisers') learning of stabilization tradeoffs beginning in the 1950s. They conclude that policymakers during the 1950s knew and "forgot" a good model, learned an inferior model to be used during the 1960s and 1970s, and later (during the 1980s) rediscovered the "good" model— what, in his commentary, Sargent (2002) labels the "Berkeley story." Economists acknowledge that all economic models are literally 'false'; no model can be rich enough to be an exact representation of the economy. Some aspects of falsity are accepted as approximations—-by definition, a model necessarily omits certain aspects of the economy for tractability. Selected judiciously, such omissions need not impair the usefulness of the model for policy analysis or forecasting. Models also may be false in ways that $d o$ impair their usefulness, including errors in equation specification and/or parameter values.

The canonical textbook model, which underpins the staff's FRB-US model, teaches that increases in labor productivity lead to increases in economic growth (real per capita GDP). In this model, accelerations of labor productivity are viewed as a positive supply shock, which reduce unit costs and accordingly boost real incomes and profits. Increases in labor productivity growth similar to that which

8 The source documents for Meltzer's book are hosted on the Internet by the Federal Reserve Bank of St. Louis as part of its FRASER project at http://fraser.stlouisfed.org/meltzer/. In this study, we distinguish studies that examine policymakers' learning processes from studies that argue that the pursuit of alternative policies during specified time periods would have produced superior economic outcomes. We also would omit from the category of policymakers' learning any circumstance where policy changed due to political pressure rather than learning. Indeed, some such episodes perhaps are best regarded as policymakers suppressing their understanding of the correct monetary policy in order to appease political pressures. Bremner (2004) relates in chapters 9 and 11, respectively, how Presidents Johnson and Nixon successfully pushed Federal Reserve Chairman Martin to compromise his anti-inflationary views. Abrams (2006) demonstrates, via quotations from the Nixon Oval Office tapes, how strong, direct, and persistent pressure was used to induce Arthur Burns to adopt policies wholly contrary to writings in Burn's own 1957 book. Subsequent re-discovery by policymakers of their earlier, more defensible principles is not an example of policymaker learning. Policy learning always includes significant differences of opinion; Meltzer's chapter 8, for example, concisely compares and contrasts such differences prior to 1951. Previous articles written within the Federal Reserve include Kozicki (1997) and Tallman (2003). 
occurred in the United States during the 1990s has occurred in other eras and in other countries, and these developments are usually associated with technological innovations to produce rising living standards. ${ }^{9}$ In most instances, analysts (and policymakers) found it difficult to recognize the occurrence of a "structural break" due to lags in the timeliness of incoming data and to subsequent data revisions. ${ }^{10}$ If there is a common thread running through the FOMC's changing model of how productivity affects the economy, it is consumer and business sentiment. What is lacking in the FOMC transcripts, however, is a "model" of such sentiment. Absent such a model, the Committee appeared to be basing its changing views on an unobserved (and unobservable) variable.

This unobserved variable, the so-called Greenspan model, was termed a black box by Blinder and Reis (2005), but nonetheless sufficient for policymaking. In their view, “economists should not delude ourselves into believing that we know enough to use precisely specified models to design quantitative policy rules to which a real central bank would want to commit for a lengthy period of time. In the world of practical policymaking, robustness is probably more important than a model-specific optimality that may be spurious" (p. 17). It is thus difficult to reject the hypothesis that the Greenspan Committee's responses to fluctuations in productivity growth were anything other than ad hoc attempts at "risk management." The FOMC transcripts from 1996 and 1997 suggest that Chairman Greenspan placed little confidence in aggregate real GDP as an indicator of the direction of the economy. Perhaps because accurate, timely data are essential for activist monetary policymaking, Greenspan shifted his focus away from GDP toward a broad array of individual-industry data. In particular, he focused on productivity growth in manufacturing and the broader nonfinancial corporate sector. One danger in such a disaggregated approach is that many industries primarily produce intermediate products that do not

\footnotetext{
${ }^{9}$ Basu et. al. (2003) compare and contrast the differing US and UK experiences after 1995.

10 Orphanides and Van Norden (2002).
} 
appear directly in GDP. ${ }^{11}$ Policymakers risk significant errors if they respond too rapidly to incoming data that later revise significantly. ${ }^{12}$

The FOMC, by contrast, was initially reticent to fully embrace Chairman Greenspan's new-economy view, and came to see more rapid productivity growth as a threat to inflation stability, in two ways. First, corporate profits and business fixed investment were increasing, contributing to stronger aggregate demand. In part, such investment reflected the obsolesce of existing (older) equipment and the shorter lifetimes of much newer equipment (particularly IT-related equipment). Second, household spending was increasing due to wealth effects. Higher corporate earnings, both current and anticipated, boosted equity prices. If the wealth elasticity of consumption was large, this caused a second boost to aggregate demand. Compounding this problem, faster output growth lowered the unemployment rate, raising the nominal wage rate and adding to the upward pressure on inflation. In this framework, the Committee came to see the productivity acceleration as increasing demand today while promising increased supply in the future. At one level, this presented policymakers with a form of a time inconsistency problem. ${ }^{13}$

In neo-classical growth accounting models used at the Board and elsewhere, labor productivity depends on capital deepening (net additions to the capital stock) and MFP. ${ }^{14}$ Against this backdrop, labor productivity entered Committee discussions in two places. First, the growth rate of potential output equals the product of labor force growth and labor productivity growth. Second, in the markup pricing model with predetermined wage growth so-often used by Committee members, more rapid productivity growth promised to reduce upward pressure on prices. For monetary policymakers during the 1990s, as it had been since 1982, the ultimate question was choosing an appropriate target level for the federal funds

\footnotetext{
11 This point is made clearly by Triplett (2002).

12 In the models of Svensson and Woodford (2003, 2004), optimal response to imperfect observation of output (and productivity) depends on the noise in the system. The optimal response to the optimal estimate of output displays certainty equivalence - but what is to be done when different policymakers have different estimates of potential output?

${ }^{13}$ Interestingly, Greenspan would argue in mid-2010 that high growth rates of labor productivity were impeding the natural upswing in job growth that accompanies an economic recovery. See Greenspan interview on CNBC's "Squawkbox," July 1, 2010. As we will document in this article, this wasn't the first instance of Greenspan pointing to pernicious effects from rapidly rising labor productivity.

14 See Anderson and Kliesen (2006).
} 
rate. ${ }^{15}$ This pattern was consistent with Greenspan's assertion that the Fed was able to be much more accommodative to faster output growth than past experience would have suggested. ${ }^{16}$

Largely ignored in the Committee's discussion, however, was the contribution of technical progress (as measured by multi-factor, or total, productivity, MFP) to increasing the productivity of existing capital. The Committee's views were reflected in discussions of a higher equilibrium real shortterm interest rate, r-star (or $\mathrm{r}^{*}$ ). R-star can be thought of as the real short-term interest rate that would be required to achieve growth of real GDP and inflation at their targets over a three-year horizon. If higher productivity increased the return to capital, then it increased $\mathrm{r}^{*}$, and the Committee was required to increase its rate target if no more than to maintain the extant stance of monetary policy. ${ }^{17}$ This is consistent with the pattern seen in Figure 3, which reproduces a chart from the "Bluebook" prepared for the June 2004 FOMC meeting that plots the actual real federal funds rate and a range of estimated equilibrium real short-term rates. In Figure 3, the estimated range of the equilibrium real federal funds rate began to rise above its historical average in 1994, where it remained until the 2001 recession.

\section{[Insert Figure 3]}

As Sargent noted, policymakers who start with a model that is perhaps flawed or incomplete, can settle on an "approximate but good enough" model of the economy. This convergence, which would characterize our description of the FOMC during the productivity revolution, thus occurs through learning and experience. However, unlike Sargent, we pursue this convergence process by examining the policy record (transcripts) rather than comparing macro modeling tools. The transcripts provide invaluable

\footnotetext{
15 Wynne (2002) discusses in detail the time-line of federal funds rate targets during the 1990s in response to incoming productivity data. Thornton (2006) discusses the FOMC's federal funds rate target beginning September 1982.

16 One might argue that employing real-time estimates would provide a better sense of the data that actually confronted policymakers at the time. Regrettably, we do not have access to that data (if it exists).

${ }^{17} \mathrm{R}^{*}$ can be thought of as the short-term real interest rate path that equilibrates actual output with potential output. The discussion of a negative $\mathrm{r}^{*}$ and its implications would also come to dominate the discussion during the 20072009 recession, as suggested by the debate over the Taylor Rule's implication of a negative federal funds rate.
} 
evidence regarding the real-world dynamics of group decision making under conditions of pervasive uncertainty. ${ }^{18}$

\section{THE FOMC DURING THE EARLY STAGES OF THE 1990s PRODUCTIVITY}

\section{ACCELERATION}

In the 1990-91 recession, productivity tended to be less discussed at FOMC meetings—-perhaps because disagreements over projections of the trend growth rate of potential output seemed less important during a recession. During the early stages of the economy recovery, as the economy strengthened, a discussion about trend productivity once again arose again. In particular, at the August 1992 meeting, then Minneapolis Fed President Gary Stern and Greenspan questioned David Stockton (Associate Director of Research) about the staff's estimated growth rate of potential real GDP and its decomposition (productivity and labor). Stockton reported that the staff estimated that the growth rate of trend productivity and labor input were each 1 percent. Greenspan asked Stockton if the staff thought that the growth of trend labor productivity might be higher than 1 percent. Stockton replied that the early stages of an economic recovery were not the ideal time to separate trend estimates from the traditionally-strong cyclical rebound in productivity that occurs for a while after the recession ends:

MR. STOCKTON: . . it's difficult to pin down what the trend in fact is. The good productivity performance that we've seen thus far in the recovery is not inconsistent with normal cyclical behavior if one were to assume a trend of 1 percent. That is in some sense how we infer what the trend is. But one could certainly say that at this stage we don't know how much of this restructuring is actually accomplishing some underlying improvement in trend productivity and how much of it is just simply using the existing work force more effectively as firms always do in a cyclical recovery. So, there's certainly a possibility that it could be better, but I wouldn't bet on it at this point. If one thinks back to where we were in the early '80s, coming out of that recession there was a tendency, I think, for many people to overestimate the improvement in productivity. There was talk then that the trend had improved to maybe 2 percent or in excess of 2 percent and it turned out to be a disappointment that as we progressed through the decade we didn't see that kind of improvement. So, I think it's always difficult when you see the good increases in productivity early on [in a recovery] to know exactly how much is trend and how much is cyclical.

\section{Anecdotal Evidence}

${ }^{18}$ See the conference volume "Monetary Policy Under Uncertainty," for a recent treatment of this topic. The papers can be accessed at: http://research.stlouisfed.org/publications/review/article/6547. 
It appears that anecdotal evidence from business contacts played a key early role in shaping Greenspan's views about the structural changes in the economy stemming from the new technologies emanating from the microprocessor. A few months later, this anecdotal evidence begins to shape his views about the productivity statistics published by the Bureau of Labor Statistics. Accordingly, it becomes apparent that Greenspan is having some qualms about the staff's estimates of trend productivity growth. The FOMC's learning experience with regard to the productivity acceleration began in earnest at the December 22, 1992, meeting. Chairman Greenspan offered a lengthy discourse on a possible shift in trend productivity growth, chastising the staff and Committee members. Greenspan said that advances in high-technology and telecommunications equipment may be starting to provide productivity dividends because of software development. This was about seven years before the BEA officially incorporated business outlays for software in its estimates of nonresidential fixed investment in October 1999. Although lengthy, we include his remarks here in their entirety because of its historical significance in setting the stage for repeated FOMC policy discussions throughout the 1990s: ${ }^{19}$

CHAIRMAN GREENSPAN: One of the more interesting aspects of what is going on at the moment-it's something that a number have alluded to-is that we basically have a productivitydriven recovery ... The outlook for that particular variable is really quite critical to a number of the issues that have been raised around this table. There is an interesting question as to whether, in fact, we can have continued strong growth without employment growth. Obviously, theoretically we can. The question really gets to the issue of whether or not this productivity surge we've been looking at is abnormal or not.

There are essentially two hypotheses about what those increases are attributable to, both of which could turn out to be right. The first is that the level of output per work hour at the bottom of the recession was quite low relative to the inputs of both physical capital and human capital. In a sense that's saying that the economy was not operating at an efficient level relative to its inputs. In that case, by just tightening up one can very readily reduce labor input and create within a certain range a rise in output per work hour. One presumes that that can continue to increase until we run up to the upper edge of that range, meaning that the existing capital, both physical and human, is being employed at its most efficient levels.

The second possibility here is that the norm of long-term productivity growth ... has tilted upward. In that case, we're not looking at 1 percent or slightly more than 1 percent [as the norm], but conceivably all of a sudden something has occurred which has changed the longer-term productivity growth [trend]. Some anecdotal evidence suggests that there is at least something to that. Jerry [Corrigan], I don't know if you remember that breakfast where we had a very interesting representation of manufacturing corporations who were raising the point that this restructuring that is going on had only really begun, which is the same issue that you were getting

${ }^{19}$ In general, the quoted text from the FOMC transcripts in this article has been lightly edited to reduce its length, and formatted into paragraphs to improve readability. 
from the New York [business leaders]. It strikes me that what may be happening-and say "may"-is that we have looked for years and years for the significant impact of productivity growth coming off the major computer input in telecommunications and high-tech capital assets and, as you may recall, we got very little of it. I think the reason is that we did not have the software. Essentially we could not really employ that degree of computational power without a major upswing in the analytic capabilities in using the equipment. In the last five or six years, or maybe a little longer, there has been a very dramatic increase in applicable software. One need only look at the stock market price of Microsoft to see the market valuation of this particular asset coming on stream. The people Jerry and I were talking to at the breakfast were talking about [unintelligible] systems manufacturing. I remember one of the people there was an old friend of mine from a company called which used to put DC motors into the rolling mills of a lot of the steel operations: that was their market. So, I raised the question: Is the big steel business now basically heavily DC motors? And he said "We don't even think that way anymore. What we think of is complete computer operating systems of manufacturing." If you go around and speak to people, what you find is that in the last two or three years there has been a major change in the way manufactured goods are created. And if you look at the data in the nonmanufacturing area, we are finally beginning to see some definite quickening in output per work hour in that area as well.

If this is the beginning of something of quite important significance, the question is whether it is in fact saying that our potential GDP is being underestimated. Something may be going on here. The trouble is that we will not be able to know that for a while. It is quite conceivable that part of the problem that we're looking at is that the marginal cost of adding new people is so great at this stage that it may be creating somewhat of an illusion about the relationship between capital and labor: it may be creating an attitude on the part of a number of managers that they just will not hire new people except under duress because the obvious medical costs, employment training, and all the other costs are very large. And the big upswing in the temporary employment rolls is really quite impressive and clearly out of line with what the previous history of temporary employment has been.

So, we may have a technical problem here which is obscuring what is going on and may be making it appear to be a much bigger issue than it is. But what is certainly the case, if the Greenbook GDP figures are right or if those figures are any stronger than that, is that we are going to get one of two scenarios. One is that we will get a very marked increase in actual employment growth, because it's difficult to imagine the average workweek going very much higher than it is. And if we are at the upper ranges of productivity growth, then the arithmetic of the system basically says that it all falls out to increased employment. The alternate scenario is that we are badly missing a major secular change in the productivity trend, in which case this is going to work out somewhat differently. It's not clear to me how it will play out in the sense that we do know that without a significant increase in employment. . .

Productivity was a popular topic, thereafter, at most Committee meetings. At the February 2-3, 1993, meeting, members noted 1992's 3 percent increase in labor productivity and challenged the staff's

forecast of a slowdown to a 1.3 percent pace. In response, the staff noted that the 1.3 percent pace, in

fact, was itself an increase from their previous projection of only a 1 percent trend growth rate. Little was said regarding productivity at the March meeting except the Chairman's comment that "Productivity is picking up in a fairly substantial way, and I suspect it is basically real." Inside the corridors of the Federal Reserve, Chairman Greenspan was thus beginning to lay the foundation for a debate between those who 
continued to see roughly 1 to 1.5 percent trend productivity growth, and those, like himself, who saw revolutionary changes occurring in the U.S. business sector. Productivity was little discussed during subsequent meetings until Governor Angell expressed his frustration at the August 1993 meeting:

I really just don't understand productivity. I don't understand how we can have a decline in productivity for the business sector of 1-1/2 and 2-1/2 percent two quarters in a row when productivity in manufacturing has been rising at $4-1 / 2$ to 5 percent! Somebody is doing very, very poorly; and if anyone knows who it is—who really snuffing on the job- they haven't been spotted yet. So, that is indeed a real puzzle.

At the following meeting in September, Governor Angell noted that the recent revisions to the national income accounts had worsened the productivity-trend puzzle. Chairman Greenspan also made clear his suspicion of the incoming data:

I'm inclined to believe that when we look back at this period with the better annualized data, which may be a year or two years from now, it's going to look better because we can't have the unemployment rate declining, the initial claims falling and, as Governor Mullins said, a tight labor market with average hours of work moving up, and have declining productivity. It just doesn't make sense. Something is wrong with the data system, and I suspect—or I hope—that eventually that will get resolved.

I'd say the economy is moving [up at a rate] that has to be over 2 percent at this point, maybe 2-1/2 percent. I realize that this may seem to be making the figure look the way I think policy ought to run, but since I don't sense that anybody out there is talking in terms of any radical changes, I won't press this issue.

The public began to see an inkling of this emerging debate inside the Federal Reserve in the Chairman's December 1994 speech to the Economic Club of Chicago. Although much of the speech was devoted to a discussion of rising worker insecurity, Greenspan argued that the Schumpeterian process of creative destruction lay behind new production processes and new types of goods and services that were displacing obsolete ones. Citing work by Stanford University Professor Paul David, Greenspan noted that there was usually a long lag between significant technological innovations and rising productivity and living standards. One example he cited was the adoption of electrical power, which gradually replaced power generated by water- and steam-driven processes. "Computer-based technologies" were a technology with similar economy-wide implications, leading to a "conceptualization of output" characterization. For example, the mainframe computer industry moved from larger corporate enterprises to the "subsequent birth and growth of many smaller and more dynamic firms." 
Sharply falling semi-conductor prices would allow smaller businesses to embrace computer technology that had previously been limited to large firms. In addition, these new technologies allowed large firms to reorganize in ways similar to the historical introduction of fractional horsepower electric motors. In the aggregate, these new general purpose technologies, as seen in Figure 4, began to boost the growth rate of multi-factor, or total, productivity (MFP). The design and adoption of Toyota's just-in-time inventory system and Wal-Mart's sales tracking and distribution system are two oft-cited examples of the application of new technologies that revolutionized the way that businesses were organized and operated. The products they produced would also change. In short, Greenspan believed that these changes muddied the data, thereby biasing estimates of output and thus productivity. While undoubtedly a positive development, Greenspan also fervently believed that these innovations clouded the perceptions of economists and economic policymakers about the economy's true performance.

[Insert Figure 4]

At the December 19, 1995, FOMC meeting, Chairman Greenspan offered "a broad hypothesis about where the economy is going over the longer term and what the underlying forces are." He argued that anecdotal evidence from industry-level sources suggested that purchases of equipment and software were changing businesses in fundamental ways. Embracing the research of Professor David (1989), and noting the shortcomings of the productivity statistics, Greenspan emphasized that major technological innovations usually take a long time to have their full impact on productivity as businesses reorganize to take full advantage of the opportunities afforded by the new technology. Becoming increasingly convinced about the permanence of this technological change, Greenspan launched into a rather long discourse about "the extraordinary impact of accelerating technologies" that was couched in historical terms:

I have a suspicion that in this period, unlike previous periods, we will find that the long-run, deepseated forces are not so gradual as to be readily dismissed in any short-term economic evaluation. I suspect that the evidence is increasingly emerging that there is something different going on, which we have not looked at for awhile. One would certainly assume that we would see this in the productivity data, but it is difficult to find it there. In my judgment there are several reasons, the most important of which is that the data are lousy. I think we have not correctly defined how to capture the value added in various industries, as I believe I have pointed out previously. Looking 
at market values, we are not capitalizing various types of activities properly. In the past, we looked at capital expenditures only as spending on a blast furnace or a steel rolling mill. Now, improvement in the value of a firm is influenced by such factors as how much in-house training they have and what type. That creates economic value in the stock-market sense, and we are not measuring it properly...

While the analogies are not exact, there is something extraordinarily obvious as we read through what he [Paul David] is saying and observe what is going on now. Firms are putting tremendous efforts into computer technology. A lot of it is wasted, as inevitably it must be, and we still have not restructured vast parts of the way we do business to fit a fundamentally new technology. It is going to take a long while to do that. It is unclear exactly how that fits into our policy process. But I think it is important to put this point on the table, and I present this as a hypothesis since it is something that we will not be sure is the appropriate assessment of our changing world for probably five to ten years.

For the Chairman, rapid increases in business profits, which were being driven by strong corporate earnings, and thus reflected in rising stock prices, were signaling gains in productivity beyond those evident in published data. ${ }^{20}$ As former Fed Governor Laurence Meyer (2004) asserted in his book, Greenspan's view of the nascent acceleration in productivity growth was formed largely by both his numerous contacts in the business sector and his abiding belief that the published aggregate data were not correctly measuring the effects of information technological innovations that businesses were claiming to have garnered. With few exceptions, Greenspan views were discounted by both the Board's staff economists and his colleagues on the Federal Open Market Committee (FOMC). But the Chairman was not dissuaded. He noted, for example, that available data suggested that the service sector had achieved no productivity gain in twenty years, an unlikely event. If this measurement was wrong, how many more were incorrect?

\section{Research Evidence}

Greenspan's doubts about the reliability of the productivity and cost data also led him to doubt the reliability of the staff's model-based forecasts of structural productivity. Resolving an apparent tension between the anecdotal data on the one hand, and the hard data and model-based estimates on the other

${ }^{20}$ The indicator value of increasing profits as a signal of increased productivity has a long history; see, for example, comments by Richmond Reserve Bank president Edward Boehne during the February 1983 FOMC meeting. The Board staff's productivity trend rate, as of February 1983, was approximately 1 percent, vs. 2-1/2 percent earlier in the post-war period. The Board staff was forecasting actual productivity growth of 2-1/2 percent in 1983 and 1-1/2 percent in 1984, driven by manufacturing with not as much going on in the services sector. In the FOMC transcripts, Board research director Kichline notes that some interesting things happened in 1982. One is that productivity started rising very early. 
hand, spurred the Chairman to commission a significant research project to assess the accuracy of the BLS' published productivity statistics. In 1996, out of frustration with existing data, Chairman Greenspan asked Carol Corrado and Larry Slifman to conduct an in-depth study of the quality of existing data. Greenspan's charge to Corrado and Slifman was to examine productivity figures by business sector. According to Woodward (2000), he also requested a study of productivity growth in the servicesproducing sectors, where little or no productivity gains had been found in the last two decades. Was incorrectly-measured data to blame? Since nominal gross sales and nominal value added likely were observed with at most modest measurement error, suspicion fell primarily on incorrect price indexes for the sectors' outputs which caused deflated real output to be too small. Although Greenspan had been questioning the productivity figures for a while, it appeared that he had convinced few, if any, of his fellow FOMC members.

The results of these research studies suggested that measured productivity growth in unincorporated services-producing businesses had decreased during the last two decades by approximately one-half percent per year. Few found this plausible in reality. The Corrado-Slifman study thus proved to be a significant piece of evidence confronting the FOMC, because it revealed significant limitations of the published data. Indeed, Greenspan (2007) would later admit that the Corrado-Slifman study was the key piece of research evidence he used against those who, using the staff's model embodied with flawed data, advocated an immediate hike in the federal funds rate to quell the potential for rising inflation pressures. ${ }^{21}$ Greenspan would later note that "this was a classic example of why you can't just decide monetary policy based on an econometric model.” (Greenspan, 2007, p. 174) Perhaps just as importantly, subsequent revisions to published aggregate BLS data converged to the more rapid growth suggested by the Chairman's anecdotal, firm-level data.

An interesting question is whether "anecdotal evidence" is an adequate basis for formulating national monetary policy. Clearly, the professional staff thought not. Yet, there was statistical evidence supporting

21 See Woodward (2000) for a detailed discussion of this episode and the mechanics of the 1996 internal study, which was subsequently published by Corrado and Slifman (1999). 
the Chairman's views; a number of published studies had explored the growing importance of IT in business. For example, Brynjolfsson and Hitt's (1996) paper had been written in 1993 and presented at a number of workshops, including the Federal Reserve. In their article, they argue that previous studies which had concluded that computers added nothing to total output were flawed because those authors sought to measure the impact of computers by searching for excess stock returns in firms with high ITrelated investment. In equilibrium, however, efficient markets theory argues that firms which spend more on IT capital should not have higher rates of return on equity than other firms. Rather than compare stocks prices and earnings, they fit an economic production-theory, input-demand model to data collected during five annual surveys, 1987-1991, of several hundred large firms. They conclude that the “...gross marginal product for computer capital averaged 81 percent for the firms in our sample." Subtracting typical annual depreciation of approximately 30 percent, annual net yields to IT investment averaged nearly 50 percent over those five years. Dewan and Min (1997) analyzed the same data for 1988-1992 using a more flexible input demand model. They noted that IT capital, for their sample firms, was 2 percent of total capital outlays in 1982 but nearly 16 percent by 1994, motivated by a 20 percent average annual rate of decline in the quality-adjusted price of IT capital from 1960-1992. Their estimated the gross marginal return for their median firm was similar to Brynjolfsson and Hitt (1996).

Ramirez and Melville (1998) examined a panel of 517 publicly traded firms. ${ }^{22}$ The firms' IT capital stock as a share of tangible assets increased from approximately 2 percent in 1987 to 8 percent in 1996, and the annual growth rate of IT capital as a share of total tangible capital accelerated to a 46 percent pace during 1992-1994, from 13 percent during 1987-1992. Among these firms, the increase in the average per-firm IT capital stock differed little between manufacturing-sector and service-sector firms. Disaggregating further, however, they found that the IT capital stocks of service-sector firms in the "transportation, communications, utilities" sector were twice as large as the manufacturing-sector firms.

${ }^{22}$ Ramirez and Melville (1998) examine large U.S. firms drawn from the Fortune 1,000 list. While 1694 firms are observed for at least one year, only 517 firms are observed in all 10 years. Average revenue, profit and number of employees of these firms aligns well with figures for both the Fortune 500 and 1,000 firms. Seventy variables are available for each firm in each year. 
Measured relative to corporate revenues (gross output), service-sector firms other than retail and wholesale trade also were more IT-intensive than manufacturing. Finally, measured per employee, services-sector firms were almost twice as IT-capital intensive as manufacturing firms. Gurbaxani, Melville and Kraemer (1998) find that a higher degree of networking within the firm, closely related to the use of PCs, has strong positive returns.

The above studies of IT capital in large firms were approximately contemporaneous with FOMC deliberations during the early 1990s (especially considering the lag between authorship and publication). Later studies of IT strategies at large firms during 1987-1996 reached similar conclusions. ${ }^{23}$ While speculative, it seems reasonable that at least some FOMC members had heard similar messages_-if not from academics, then at least from their contacts in the business community. Still, it seems apparent from the transcripts that discussions surrounding the empirical findings and implications of recent academic papers are very rare in the policy discussion.

Meanwhile, the Board staff remained skeptical about a productivity acceleration due to IT investment. This was apparent in the Board's February 1997 Monetary Policy Report to the Congress. However, at the February 4, 1997, FOMC meeting, which occurred prior to the Chairman's testimony and public release of the report, Greenspan had been somewhat more blunt in response to suggestions that productivity growth had not picked up as much as he asserted:

So, the productivity gains implicit in these data [anecdotal reports] are larger than the ones we are getting in the official data. The one thing we know about the official data on productivity is that they are wrong.

Wynne (2002) notes that not until 1998 did indications appear in public that the FOMC was becoming confident of an increase in trend productivity. A year later, in the February 1998 Monetary Policy Report to the Congress, the Board staff wrote that higher levels of IT investment "may finally be translating" into faster trend productivity growth. In the July 1998 Report, the Board noted that productivity growth had picked up to approximately $1 \frac{1 / 2}{2}$ percent per year on average over the previous three years.

${ }^{23}$ See Brynjolfsson and Hitt (2003) and Melville, Kraemer and Gurbaxani (2004). 


\section{THE NEW ECONOMY COMES INTO FOCUS AND BEGINS TO CONFRONTS INFLATION}

Throughout the 1998 transcripts, the FOMC's familiar model of inflation was evident. Seldom in the Committee's discussions are views expressed that prices of significant goods and services are set by supply and demand. Rather, prices are set as a sticky markup over unit labor costs which, in turn, are algebraically determined by wage rates minus labor productivity. Wages, unlike goods prices, are sensitive to imbalances between demand and supply_-"excessive" demand for labor induces increases in wage rates beyond increases in labor productivity, leading to inflation. Although explicit statements are few, implicitly the Committee appears to have adopted the familiar textbook microeconomic model in which each firm produces near the bottom of its average cost curve, and industries display constantreturns-to-scale behavior due to entry and replication of existing firms (of minimum efficient scale).

At the February 3-4, 1998, meeting, the Federal Reserve Board research director (Mike Prell) noted "The projected growth of output is slower than potential, and thus we anticipate an easing of pressures on resources. ...favorable supply conditions--including strong productivity gains and the availability of cheap imports—will be restraining price increases as the economy expands moderately." The staff projected slightly slower productivity growth during 1998, as the economy slowed, with a return to trend growth in 1999. But the meeting also contains an enlightening discussion between Mr. Prell, the Board's deputy research director David Stockton, and Chairman Greenspan regarding the dynamic relationships between labor compensation and productivity, a discussion immediately relevant to the Committee's scheme for projecting productivity growth:

Greenspan: How significant is the correlation between nominal compensation and productivity?

Mr. Prell: I don't know the answer to that question, but I suspect the correlation is very weak in the short run. In fact, we get some of our largest compensation increases when productivity increases are beginning to fall near the end of a cyclical expansion.

Mr. Stockton: One can put nonfarm business productivity into a wage equation and actually see whether or not productivity is an important factor explaining nominal wage gains. The statistical effect turns out to be marginally significant at best. We know that real wage aspirations, loosely based on productivity, ought to be an important factor in conditioning wage demands, but businesses may not be willing to grant the wage increases. To the extent that fluctuations in productivity do not show up in wages, the first round effects will show through to profit margins rather than nominal compensation. 
Chairman Greenspan: The reason I ask the question is actually the reverse; it relates to anecdotal indications that when nominal wages are beginning to accelerate, then business escalates its efforts to reduce costs and improve productivity. So, if that model were functioning in a meaningful sense, then a significant rise in nominal wages could very well merely reflect the fact that productivity was rising and therefore unit labor costs were not.

This exchange highlights a crucial aspect of the Committee's framework for discussion: To what extent are wages predetermined almost completely independent of expected future productivity? To what extent are changes in productivity likely to affect inflation? As we will discover, in a couple of years this discussion will come to dominate the FOMC's policy discussions as it attempts to discern inflation trends.

Several Reserve Bank presidents discussed inflation in similar terms: Changes in supply conditions, including fluctuations in productivity growth, affect inflation-not imbalances in the demand and supply of goods and services. San Francisco president Parry notes "It is likely that economic activity is being boosted and inflation held is being held back to some extent by a positive productivity shock." Philadelphia president Boehne noted “...the disinflation process has had surprising staying power. Wage gains continue to be offset by productivity gains, so inflation is falling while corporate profits remain high. ... If businesses cannot get more volume out of existing resources, they undertake additional rounds of downsizing." Governor Phillips expresses a somewhat more cautious view: "Although increases in compensation costs have been offset by increases in productivity, it is questionable as to how long that process can continue. Since the U.S. economy is service-oriented and costs are under pressure in that sector, it is hard to believe that aggregate inflation will be held at bay forever..."

As of this meeting (Feb. 1998), staff estimates are nonfinancial corporate productivity growth at a 2.1 percent in the fourth quarter and cumulative Q4/Q4 1997 of 3.2 percent—a full percentage point higher than the same four-quarter period during 1996. Chairman Greenspan, in his remarks to the Committee, emphasizes a model in which wages are determined almost exclusively by labor market conditions and productivity simply reduces the pass-through of such wages into unit labor costs and, via a markup, into prices. Speaking of possible new demand from Asia, he notes "The only thing that can keep prices stable is what has been keeping them stable all along in an accounting sense, namely, productivity. 
Productivity gains clearly have kept increases in unit labor costs at a very modest level; indeed, the latter have shown no signs of accelerating during the last several quarters."

The March 31, 1998, meeting begins with a mea culpa between Prell and Greenspan, acknowledging Greenspan's previous-meeting insistence that the staff's real GDP growth forecast was too low. But a conundrum persists: the staff GDP growth forecast has increased to a 3.1 percent pace, but labor markets are even tighter-combined, the staff forecasts imply a decrease in first-quarter labor productivity at a negative 2.2 percent rate. Prell argues that such a drop is not "implausible" given the increase in labor productivity during the previous two years relative to the staff's underlying trend: "If we have it right, a movement back toward the trend line was to be expected over time-and, given the erratic character of the series, a substantial drop in some quarter would be far from shocking." Prell further notes that the BEA measures productivity from the expenditure side of the national income accounts, and that the income side has been growing more rapidly—perhaps suggestive of measurement error. He also notes that GDP growth at 4 or 5 percent "is not totally implausible."

The discussion continues as other presidents contribute stories of productivity improvement, but all lead the members to the same point: extreme uncertainty surrounds both the near-term and long-run trend in productivity. Several members note that the staff's labor market projections, combined with the productivity projection, imply sharp increases in unit labor costs and, given the Committee's markup pricing analytical framework, inflation—-the staff's projection for productivity implies a projected 3 percentage point increase in core CPI and core PCE price indexes. Governor Meyer is among the most concerned: "[these] latter developments, interacting with a slowdown in productivity growth, suggest the potential for a less benign than projected path of labor costs in coming quarters. Looking to 1999, I also am concerned that there might be a somewhat sharper reversal in the supply shocks than projected by the staff." Events were to prove Governor Meyer's concern unfounded, as productivity accelerated. Chairman Greenspan expanded on an earlier comment, by noting that "the productivity numbers are reasonably strong and the absence of pricing power is still very much a factor in holding down inflation." Accordingly, the Committee subsequently agreed to maintain the level of the federal funds rate target but 
switch to an asymmetric directive, saying in the minutes: "but additional improvements in productivity growth could not be counted on to offset further increases in the rate of growth of labor compensation, which were more likely to occur if labor markets were to tighten further."

The May 1998 meeting brought few surprises. Once again, the staff projected slower gains in productivity moving forward, interpreted as a risk of increased inflationary pressure. At same time, responding to data revisions, the staff increased their estimate of trend, or structural, productivity growth to a 1-1/2 pace — but, as typical of such revisions, the revision was cautiously small. This change once again highlighted a tension in the Committee's learning of more rapid productivity growth: Why should it be expected that an increase in trend productivity growth will reduce trend increases in unit labor costs and prices, when economic theory suggests that long-run increases in wages and productivity move together (indeed, are simultaneously determined)? Some Committee members were skeptical, including vice chairman McDonough, but Chairman Greenspan re-emphasizes his faith in the productivity acceleration: "The more interesting data provide increasing evidence that the underlying trend of productivity is moving up." Discarding the noncorporate sector as having data of questionable accuracy, Greenspan advocates adjusting hours data for the length of pay periods—doing so suggests that labor productivity accelerated during the previous two years from a 2.7 percent to a 3.2 percent rate. The first quarter's rate is 3.4 percent. The chairman concludes that the trend has increased relative to the distant past but is holding steady because of a pickup in capital deepening, and some acceleration in TFP. He also reinforces his view that the structural break in trend productivity occurred in 1995.

Regarding the supply side effects of productivity growth, the June meeting is "more of the same." However, this meeting is important because Chairman Greenspan introduces his somewhat ironic concept of a "virtuous wealth cycle" wherein gains in productivity engender increases in inflation, rather than decreases. Since this view, eventually, comes to dominate the Committee's discussion, it is worth quoting at length:

Everyone has been wrong by underestimating domestic demand and wrong in the other direction by overestimating inflation. The area where the error is crucial has been productivity because as productivity growth has accelerated, expectations about earnings over the long run have moved 
up. This has created a major increase in stock prices and a virtuous circle wealth effect. We end up with (1) much higher domestic demand and (2) lower prices because of the acceleration in productivity that has occurred. The Greenbook forecast incorporates a significant slowdown in earnings growth, which in turn comes largely from a slowdown in productivity gains. If that happens, then the growth in spending on capital goods also slows and that creates some negative internal multipliers that conform total spending to the Greenbook forecast of much slower expansion of demand. The only thing that presumably could keep the stock market on a rising trend is that we are wrong again on productivity. That would mean that earnings expectations, which are now in the area of 13 or 14 percent over the five-year time frame used by security analysts, would continue to move up, stock prices would continue to move up, and effective demand would continue to rise quite substantially. The unanswered question is what would happen to inflation in that context. That is why I think the crucial error in our forecast models has been the productivity numbers. I believe it is a mistake to view the issue of having been wrong on the real side independently of also having been wrong on the inflation side.

Via this mechanism, virtuous increases in labor productivity generate increases in wealth that, in turn, generate increases in demand to absorb any increase in output. But, to the extent that demand accelerates before supply, inflation pressures might increase, rather than decreases, when productivity accelerates. This somewhat counter-intuitive mechanism, with its unusually strong wealth effect in consumption, later will puzzle analysts and the public when the Committee increases its interest rate target at times of accelerating productivity. ${ }^{24}$

\section{RISING PRODUCTIVITY AND THE VIRTUOUS CYCLE RUN AMOK}

During the late 1990s, the staff inaugurated the practice of including longer-run simulations in the Bluebook as a complement to the shorter-run simulations contained in the Greenbook. In the staff's simulation, which was reported by Don Kohn (then Director of Monetary Affairs), productivity growth was increased by 1 percentage point in 1999 and sustained at that level for a decade. Kohn notes that "The simulations provide the cautionary note that these favorable effects on inflation are temporary.... inflation will begin to pick up if unemployment is held at that lower rate, even if the trend in productivity is tilted up permanently." In a twist, Kohn outlines a mechanism through which the more favorable productivity growth may tend to accelerate inflation-a mechanism that recurs in later Committee discussions: "A faster trend for productivity increases demand substantially, as the accelerator effects

24 For some perspectives on thoughts at the Board of Governors on the wealth effect during this period, see Gramlich (2002) and Dynan and Maki (2001). 
associated with attempts to keep capital growing in pace with the more rapid growth in output cause investment to jump, and as consumption rises with permanent income. However, supply only picks up gradually, in line with faster productivity growth, and real interest rates must increase to forestall inflation." Via this mechanism—which recurs in Committee discussions—more rapid productivity growth is "bad" for the economy because it tends, via a wealth effect, to increase near-term aggregate demand more than supply, leading to inflation pressures that the Committee must combat with higher interest rates.

Nevertheless, the year 1999 was to see little change in the Committee's views, as incoming data reinforced their view that an increase in inflation was unlikely. Chairman Greenspan noted the close correspondence between movements in labor compensation and productivity, leaving unit labor costs and inflationary pressures absent, as unit labor costs for nonfinancial corporations increased over the four quarters of 1998 just 0.2 percent, as compensation per hour rose 4 percent and productivity 3.8 percent. Although it is expected that in the long run labor will eventually capture the value of increased labor productivity, the Chairman saw a puzzle as to why, in the tight labor market, labor was not garnering more and why firms were not increasing prices more rapidly. The Chairman argues that a "fundamental" change has occurred in the economy, in part because of the forces of globalization. He further argues that the staff's projections of increasing inflation are wrong and that the Committee should accept his projections rather than those of the staff. His exposition is lengthy but, in our opinion, extraordinarily valuable because, in addition to persuading the Committee to delay policy tightening, it initializes the context for later Committee discussions of productivity and inflation that culminate in the "deflation scare" and "quantitative easing" of 2003:

...we cannot find inflation in either the CPI or the PCE index for December, and we surely do not find it in the pipeline data anywhere in the system. I submit that interpreting these results requires a fundamental reassessment of how we look at the world.

How is it possible, first, for hourly compensation growth to be flat or falling in an ever-tightening labor market? Let me begin by suggesting what does not explain it. You may recall that two or three years ago I was arguing that fear of job obsolescence was a major factor suppressing the nominal increase in compensation per hour. That factor clearly has not gotten worse; if anything, it has eased. 
The evidence, anecdotal and otherwise, suggests that the explanation lies in pressure coming from employers, who have apparently lost virtually all pricing power-an issue that a number of you raised in our discussion yesterday. We saw quite similar episodes during the long period of the gold standard, which produced price stability on average prior to the 1930s, although obviously there was a lot of price volatility. During that period, wage increases were limited by the exogenous price capping of the gold standard. The technologically driven process that is breaking down barriers to cross-border trade today has apparently created an environment that simulates the old gold standard forces. One way of looking at this is that in earlier decades when there may have been excess capacity or excess potential in one part of the world, it didn't matter because that excess could not be moved to another part of the world. But in the current more technologically advanced environment, as barriers come down we get an increase in potential supply relative to total actual physical capacity in the world economic system. And it is conceivable, but by no means provable, that globalization--the major force that people are talking about--may be having an impact on the price level, and our price measures may be reflecting that. It may also be, with regard to my previous discussion of compensation gains, that the data are capturing that phenomenon, although the argument I am making is global as distinct from a specific manufacturing issue. The argument is basically that tradable goods prices are being significantly held down by excess world capacity and that the arbitraging into the nontradable goods areas that occurs within economies, largely through wages, is the reason why service price inflation, which arguably has very little in the way of direct international globalization components, also has been restrained appreciably. In the United States this process has been augmented by a dramatic increase in the backlog of new technologies, which is an issue we have discussed in the past. This really gets down to the question of whether the synergies that have evolved over recent years have created a large pool of potential capital investments that firms can dip into to obtain a rate of return in excess of the cost of capital. We have seen considerable evidence of this in the sense that rates of return everywhere seem to be moving up. There has been a very interesting pickup since 1994 in the average rate of price decline in the high-tech area of the economy. Through the early 1990s, the deflator for computers, communications equipment, and other high-tech goods was going down at an annual rate of about 4 percent. Starting in 1994, the rate of price decline fell off the chart, and the most recent data suggest that high-tech prices are dropping at an annual rate somewhere in the area of 17 to 18 percent. Thus, even though that sector's share of GDP is only a few percent, these price declines are having an appreciable influence on the overall inflation rate.

What this implies is that we are getting a rapid increase in opportunities for investment in new technology. It is overwhelming the expansion of demand, and the acceleration in the downward adjustment of prices suggests that we have a very large backlog of unexploited investments that, as they are implemented, are displacing labor and effectuating a very significant increase in multifactor productivity. That in turn has spilled over into labor productivity. Indeed, estimates produced by the staff's econometric model suggest that we have seen a fairly dramatic pickup in recent years in multifactor productivity consistent with this process. I don't believe that transitory factors can explain the failure of models to forecast successfully in recent years. I suspect that what we have here is a missing variable, if I may put it that way. Certainly, judging from the slowing in the rate of PCE inflation, supply generally appears to be overwhelming demand despite the evident continued decline in unemployed job seekers.

As usual, Committee members express little disagreement with the Chairman's analysis. St. Louis Federal

Reserve President William Poole sees the causal mechanism differently. Seeking to place the maintenance

of low inflation at the forefront, ahead of the productivity gains, he argues capital deepening and

subsequent productivity gains are the result of low, stable inflation expectations:

We need to be talking not just about the setting of the federal funds rate, but about the policy strategy from which the current rate setting arises. 
The ideal situation, if we knew how to do it, would be to peg the rate of inflation at a very low level and go for price stability, letting the real economy run wherever it wants to run. What we would all like to see happen is to have the maximum possible employment and productivity growth consistent with price stability. The problem is that there seems to be so much evidence that the real economy leads the cyclical process, with inflation coming later. We should not ignore the anecdotes about very tight labor markets. Credit conditions and monetary growth are both very clearly on the stimulative side. The financial turmoil that motivated this Committee last fall [the Russian bond default] appears to be mostly behind us. Over the course of this year, starting sometime this spring, I think it is going to be appropriate to be tightening up on the funds rate.

At the March 1999 meeting, the staff increased its estimate of trend labor productivity growth, albeit only by one-tenth of a percentage point, beginning in 1995. The staff's new estimate of structural productivity growth in early 1999 was 1.9 percent, which was appreciably higher than the average of private sector forecasters surveyed by the Philadelphia Fed (as seen in Figure 2). Private sector forecasters, like many "new-economy skeptics" on the FOMC, appeared to be late to revise upward their estimates of structural productivity. In 2000, they boosted their trend productivity estimate by nearly 1 percentage point to 2.6 percent - a huge increase. Noting the possibility of accelerations in productivity, Board research director Mike Prell warned the Committee that such a development might require higher interest rates to forestall inflation, as gains in demand outstrip greater supply.

Some FOMC Members expressed reservations regarding the certainty that more rapid productivity growth will continue. Boston Reserve Bank President Minehan noted the Board staff's trend rate of productivity growth during the last several years, first fell to less than 1 percent and then about doubled. The Chairman seeks to rally members to his viewpoint by acknowledging past errors-in part because of the "missing variable" he noted at the previous meeting. He is now assuring members that the staff now has it correct. Moreover, the Chairman returns to his view that the data are flawed and therefore providing a misleading view of labor productivity trends:

For quite a while our Greenbook and indeed all models have been projecting slower economic growth and higher inflation than actually have materialized. Looking back, it is conceivable and perhaps likely that the major explanation for these projection errors is that the models have missed the extent of the acceleration in productivity. By that I mean that the cyclically adjusted rate of increase in productivity, as now shown in the data, has been rising appreciably since the mid1990s. The evidence of this in the underlying data is fairly clear-cut. That is, the speed-up of productivity growth can explain to a large extent both the significant acceleration in GDP from the supply side, as a number of you have indicated, and the suppression of unit labor costs and total unit costs more generally, which in turn explains the softness in inflation. . I think the question on the table is whether we are looking at an aberration or at the emergence of a new era. 
The difficulty that I have in looking at overall business sector productivity is an issue that we have discussed previously, namely that the measurements we see in the corporate and the noncorporate areas cannot be reconciled. The margins of noncorporate profits, if I may use the term, are not bad. Yet the implicit output per hour number in total business sector productivity or nonfarm business sector productivity is picking up an implicit output per hour number in noncorporate business that has been declining, on balance, for two decades. For example, in industries where we have very significant amounts of noncorporate business - the legal profession, the medical profession, and business services-measured annual productivity has declined about 2 percent per annum on average since the late 1970s. That is just not credible. So, we have a major measurement error problem in the noncorporate area that distorts our view of what is happening to productivity.

At the May 18 meeting, the staff added another $1 / 4$ point to their estimate of trend labor productivity growth, and, reflecting cyclical tightness, an additional $1 / 4$ point to the near-term forecast. Board research director Mike Prell summarizes the inflation outlook as quiescent for now but perhaps problematic for the future by noting that the staff and many bond market commentators believe that "the best news on inflation is behind us." An unusually long discussion with Reserve Bank presidents follows. Typical is President Parry, who seeks an estimate of the uncertainty of the productivity forecast:

President Parry: Mike, I have two questions, and the first one is on productivity. Estimates of the productivity trend seem to have been revised quite frequently in the last few years. To me, this suggests greater uncertainty about the productivity forecast. Wouldn't you have to conclude that the uncertainties associated with our forecast of real output and inflation must be greater given the uncertainties that are associated with the productivity forecast?

Mr. Prell: If the locus of the uncertainty is productivity, I'm not sure that we are more uncertain about it now than we were three years ago or six years ago. I think there has always been a considerable band of uncertainty around the prospects for productivity. We were puzzled by why productivity gains were so low for many years. I guess I don't feel any more uncomfortable on that score. The only way I feel uncomfortable is that, in a sense, we are moving a bit beyond the pack. But I think others are moving up their assessments of productivity trends, too, as they overcome the basic scientific skepticism reflected in the often heard statement that this recent experience isn't yet a statistically significant deviation from the previous trends.

The learning process of the Committee is highlighted as the Chairman seeks to deflect Reserve Bank presidents' challenges to his (and the staff's) forecast. The presidents questioned the staff's ability to separate cyclical from structural changes in productivity growth-Chairman Greenspan had defined cyclical changes as firms' efforts to expand output in the near term without increasing employment, and structural productivity as changes in business process such that the labor requirement per unit of output is permanently reduced. The Chairman admits that “ the truth of the matter is that I don't see how we will know which is which until after the fact." Governor Meyer also was outspoken, arguing that perhaps the 
staff has gone too far with its increases in the trend rate, while at the same time admitting that "the staff's pattern of incremental steps in trend productivity growth makes sense":

My problem with the staff forecast is that its projection of a $2 \frac{1}{4}$ percent productivity trend over the forecast period [Note: the following 8 quarters] is just too aggressive for my taste. This revision to the productivity forecast basically drives their entire forecast. . . One question we have to ask is whether we have become sufficiently optimistic about the productivity trend going forward to justify keeping in place the full amount of the decline in the federal funds rate that was motivated by a forecast that has since been so significantly revised and by a set of financial conditions that have so dramatically improved. The second question we have to ask is whether we should maintain the current policy setting for the funds rate if growth continues strong and labor markets tighten further while inflation remains steady in the near term and is projected to increase thereafter.

Governor Rivlin expressed similar skepticism. Clearly, the selling of the idea of a "New Economy" with more rapid eternal productivity growth was going slowly. Monetary Affairs' director Kohn and Chairman Greenspan, in part, agreed. Director Kohn noted that 4 percent output growth during the last four quarters had been fully accomplished with productivity gains and little labor market tightening, plus decreases in some broad measures of nominal wage and price increases.

Chairman Greenspan walks a tightrope by echoing Kohn's summary of the economy's performance while acknowledging that dangerous imbalances are cumulating — tightening labor markets, strong productivity growth, and an absence of inflation. Greenspan responds much like he did in the previous meeting, by pointing to the rapid growth in productivity that was holding down unit labor costs and thus prices and bolstering earnings and productivity. Moreover, says the Chairman:

The earnings forecasts and productivity growth rates may differ, but the two are interrelated. Because we are talking about a forecast with no change in labor's share, an increase in expected earnings over five years has to show up either in an acceleration in the rate of inflation, in the rate of productivity growth, or in the rate of hours growth. The latter is extremely unlikely, strictly as a matter of demographics. There is very little evidence to date of a pickup in inflation expectations, and until very recently the notion regarding pricing power in the business sector has been uniformly that it is zero. Theoretically, it is possible that foreign affiliates are increasing their share of the earnings. But given what has happened to oil, that seems doubtful. . . Therefore, we are led to the conclusion that the earnings expectations are essentially projections of productivity growth.

In a mild rebuttal, President Broaddus brings forward Chairman Greenspan's own virtuous circle argument—now in favor of the policy tightening that the Chairman asks to defer:

Mr. Chairman, my preference would be to go ahead and move the funds rate up $1 / 4$ percentage point today. To me it seems increasingly likely that trend productivity growth is rising. Some may see that as a reason to stand pat on policy, but higher trend productivity growth will lead at least 
some households and businesses to expect higher incomes in the future. Some are going to try to act on that expectation now by borrowing to increase their spending even though the actual increase in output is not yet available. In that situation, interest rates need to rise to keep demand from becoming excessive. The extraordinary growth in domestic demand of late seems clear if one looks at a measure like private domestic final purchases, which grew at an annual rate of $7 \frac{1}{2}$ percent in the first quarter after growing at a rate of $61 / 2$ percent last year. That has to be above any reasonable estimate of the sustainable growth in output, and it is one reason for tightening policy.

By the June 1999 meeting, the staff's projection of trend, or structural, productivity growth was greater than other forecasters. Board Research director Mike Prell noted that the Council of Economic Advisers had increased its projection to a 1.6 percent rate, versus the Board staff's 2-1/4 percent pace. Committee members appeared increasingly reluctant to accept further large increases in productivity's trend. Chicago Fed President Moscow cites an academic study asserting that there has been no broad acceleration. Boston Fed President Minehan asserts an opposing position: "when I look at our track record at the Federal Reserve Bank of Boston and the track record of the Committee in general, we have been underestimating growth and overestimating inflation for some period of time." 25 The uncertainty of the relationship between the productivity acceleration and the economy's underlying "equilibrium" real interest rate was raised by several members. Once again, Richmond Fed President Broaddus noted that higher structural productivity growth rates were a signal of higher future real incomes and thus expenditures and equilibrium real interest rates. [This is consistent with the discussion surrounding Figure 3.] In his view, an increase in the FOMC's nominal interest rate target was needed to preclude an easing

25 At this meeting, even a discussion of Humphrey-Hawkins money growth rate targets became entangled with productivity growth. Increasing productivity growth argued that more rapid money growth would be consistent with price stability. The Chairman argues against such an increase in target ranges because it would "inexorably" lead to a discussion of the staff's process for developing productivity projections - a topic he did not care to debate or defend in public. Ironically, the Committee accepts the need for reduced disclosure and transparency. The Chairman says: "we have managed to take this whole issue [projecting productivity growth] off the table completely. If we change the [money] targets and we try to explain why, what of necessity is going to come out in the explanation is that we have changed our structural productivity growth measure from 1 to $2^{1 / 4}$ percent, and that is something we have avoided doing. All we would be doing if we change them [money targets], as far as I can see, is to open us up to discussing what the staff's trend productivity number is and then we'd get involved in defending it or not defending it. I feel like the politician who spends most of his time trying to avoid having certain questions asked. This is one of those questions I would just as soon not have raised because I think there are differences of view among the people in this room and it would serve no useful purpose of which I'm aware to get into this discussion." 
of monetary policy. Evidence for such a strong wealth effect, at least among materials presented to the Committee, was absent. ${ }^{26}$

At the August meeting, cracks appear in the tide of sentiment regarding continued acceleration of productivity. Concern that productivity growth may slow are amplified by simulations included in the Greenbook. The staff discussion surrounds predictions that inflation will accelerate if productivity slows and labor markets tightness remains. As some of the new-economy skeptics had been arguing, inflation began to accelerate in mid-1999 from the 1 to 2 percent rate seen from 1997 to early 1999 , to 3 to 4 percent from early 2000 to mid-2001. As a result, as seen in Figure 5, one-year ahead CPI inflation forecast errors, which were negative for most of the 1990s, began to turn positive in 2000. [NOTE: A negative forecast error means that actual inflation was less than forecasted inflation, or, equivalently, forecasters were consistently predicting inflation to be higher than what it turned out to be.]

[Insert Figure 5]

Suddenly, the Committee is faced with the prospect that slower productivity growth will engender more rapid inflation — when, only a few meetings previously, the concern was that faster productivity growth would engender more rapid inflation. Was the productivity acceleration always bad news for the inflation outlook? Governor Meyer's comments are typical:

I read the recent data as consistent with a continued momentum in aggregate demand that is likely to support growth at or above trend in the period immediately ahead and maintain very tight labor markets. I see core inflation stabilizing amid signs of a dissipation or reversal of many of the favorable supply shocks that have contributed to low and declining inflation over the last couple of years and stirrings, perhaps, of higher wage gains. This sets the stage for a test of the role of tight labor markets on inflation going forward ... I expect we all look forward to learning a little more about just how new the new economy really is. The story in the Greenbook-and one that I can definitely relate to-is that the dissipation or reversal of favorable supply shocks, including the stabilization in trend productivity growth, will allow the effects of prevailing tightness in the labor market to show through. We will maintain growth at near trend over the forecast horizon with gradual upward pressure on inflation.

Chairman Greenspan fights to hold the Phillips-curve inflation hawks at bay, while at the same time acknowledging the risks and uncertainty of predicting productivity growth. As before, he bases his argument on the nexus between productivity and unit labor costs. Holding the members together is

${ }^{26}$ See footnote 21 , above. 
difficult; his lengthy, detailed remarks aptly demonstrate his strength as a consensus builder. While we

have edited lightly for brevity, the strength of his argument is appreciated by its detail. In the end, he

grants the hawks a 25 basis point increase in the federal funds target:

The point that I'm trying to make here is that we don't have any real evidence that inflation has risen. Indeed, we are still looking at declining rates of increase in unit costs. And if profit margins are rising, that basically says that some of the increase in prices or the lack of decline in prices has to be reflected in widening profit margins. So there is still a gap there. In other words, the inflationary pressure is not there. Now, I don't deny that if we proceed with the product-based GDP numbers and project a stable productivity growth rate, that will produce an acceleration in the CPI growth rate. There is no algebraically conceivable alternative to that. But that is begging the question, because unless and until we see some slowdown in productivity growth, then the argument that inflation is about to bite us is not credible.

I do not deny, as I've said previously, that the growth of output per hour is going to slow down, but I don't know when. There is no evidence of that yet, and there is no reasonable upper limit in the near term. The crucial point here is that we became so used to a 1 percent increase in productivity growth over a very long period of time-from the ' 80 s into the '90s-that we have looked at the gap between potential and actual as entirely a demand-side phenomenon. . . But now we have the supply side moving, and the question of whether the economy is overheating and inflationary pressures are mounting cannot be strictly an issue of what is happening on the demand side. That's because if productivity is accelerating, of necessity it has to be balanced in some manner, as I said last time, by very high expenditures for motor vehicles, housing, constructionbig everything - unless we get a big statistical discrepancy, bigger than the one we're looking at now.

The truth of the matter is that we have a very strong economy with very marginal indications of any slowing. But the question that is still up in the air is whether, in fact, it is an overheating economy. .. We know the gap between potential and real output is in the area of less than $1 / 2$ percent without claiming any knowledge of what the actual potential is because we don't need to know that. All we need to know is the difference.

What I'm suggesting is that we still should be looking for the answer to the question of "Where is the inflation?" It is not showing up anywhere in the basic price data, at least that I can tell. And the people out in the business world with whom I talk, and it's a fairly extensive group, keep complaining about their inability to raise prices. I do think that wages will continue to increase if productivity growth continues to rise. But since this would mean that unit labor costs would be little changed, that won't be a source of price pressures. In any event, having said all of that, so far as the domestic side is concerned I think the availability of resources is very tight. Inflation is clearly prone to acceleration should the increase in the growth of productivity slow or even stabilize. That hasn't happened yet as far as I can tell. . . My bottom line is that I think we have to tighten by 25 basis points.

At the October 1999 meeting, members again expressed concerns that the policy risks were unbalanced toward higher inflation if the productivity acceleration was permitted to "run its course." The inflation hawks openly challenged the Chairman's opinion that the risks, at worst, were balanced. In the Greenbook, the staff (again) forecast somewhat slower productivity growth and more rapid inflation. 
Governor Meyer argued that the broad outline of the forecast resembled his "typical" Board staff forecast since 1996, featuring slower growth and higher inflation. In his mind, the recent acceleration of output growth reflected favorable financial conditions and fiscal stimulus. No mention of the Greenspan virtuous cycle:

By my count there are nine factors that contribute to higher inflation in this forecast: (1) tight labor markets today; (2) tighter labor markets around the corner; (3) rising capacity utilization rates; (4) a rebound in nonoil import prices; (5) the secondary effects of the sharp rise in energy prices this year; (6) a rebound in benefit costs; (7) an increase in the minimum wage; (8) an upward trend in nonoil commodity prices; and (9) the stabilization in trend productivity growth. There is an important partial offset from an assumed declined in energy prices over next year and the following year. But the cards seem stacked. To be sure, this is just a forecast. You might say, "Been there, done that!" [Laughter] Maybe productivity will accelerate further; I cannot rule that out. Maybe NAIRU is even lower than the staff estimate; it could be. . . But I find the Greenbook story line compelling. If it is wrong, it is likely to be a matter of degree rather than direction.

The Chairman digs in his heals! He is accepting none of this quiet rebellion. In a soliloquy so long that even taciturn Chairman Greenspan labels it "a long lecture," he challenges the staff's macroeconomic models and questions whether the models' foundations are adequately dynamic to capture the extraordinary supply-side changes that he recognizes. Recall that a few meetings earlier he was telling the FOMC members that the staff had finally got things right! He suggests that the staff and Committee members are misreading incoming economic data. The passion and depth of feeling is revealed in a discussion framed in the language of calculus_-perhaps a first for the FOMC — rather than the typically more circumspect language of seeking to balance risks. The Chairman argues that correct policy action hinges on one's judgment regarding the magnitude (and sign) of a second derivative. He implores the Committee to adopt his judgment that the staff models inadequately capture interactions between the demand and supply sides of the macro economy, and to maintain the federal funds rate target so long as evidence of increasing inflation is absent [the Chairman's remarks are edited to reduce length]:

We have a very difficult set of issues to evaluate. The reason relates largely to what I see as growing evidence that the models with which we have been trying to explain how the American economy functions are becoming increasingly obsolete. It is not that the econometric structure of the models is inappropriate, but certain simple assumptions are made in their structure that are driving the results we observe and are creating at least the presumption that we are missing something important. 
In my judgment our models fail to account appropriately for the interaction between the supply side and the demand side largely because historically it has not been necessary for them to do so. A crucial variable in our models is trend productivity growth, and the conventional procedure in our quarterly forecasts is to specify a constant trend rate of productivity growth. Yet, our official figures indicate that the growth in productivity has been moving up at an annual rate of around $1 / 2$ percent each year since early 1997. On top of that, the review of 1995 to 1997 in retrospect is adding another 0.3 percentage point to the annual rate of growth in the most recent years. So what we have, in effect, is a set of trend productivity values whose second derivative has been positive.

We have two choices. We can either project a continuation of the positive second derivative for productivity, or we can assume that the second derivative goes to zero and we will have a flat productivity growth rate. You may say that there are arguments for both. And indeed, as I will make a case in a moment, there are. But we have chosen the second automatically.

What is the case for automatically assuming that the second derivative of productivity goes to zero? Certainly the most recent productivity data-whether we are looking at growth rates calculated on a four-quarter moving average basis, a two-quarter basis, or any other basis we want to use-do not confirm that assumption because all those data indicate that the rate of growth in productivity has been rising. Then the question is why this happens. When we engage in growth accounting analysis in an effort to get to the bottom of this, we find, as Governor Ferguson said, that there has been a very significant increase in capital deepening. That means, in effect, that we are getting very substantial acceleration in the growth of the stock of capital—or, to be more precise, capital services. In addition, we clearly are getting evidence of acceleration in multifactor productivity, the residual in growth accounting, which is another way of saying that the synergies of productivity-enhancing investments are coming together and in the process are creating an acceleration in productivity. What this implies, if it is true, is that we should be seeing a fairly marked upswing in profit margins or, another way of looking at it, in the ratio of profits to compensation or to a variety of other measures that productivity may spill into such as real wages.

If we look at a breakdown of the supply side of the economy, what we end up with is that the total change in GDP is algebraically equal to structural productivity growth plus the growth in the labor force or the working age population or some similar measure. And leaving aside a number of minor issues such as average hours and statistical discrepancies--which are not unimportant--we find that the measure of the difference between the change in GDP and the sum of labor force growth plus structural productivity growth is effectively some measure of changing unemployment. And declining unemployment is very likely the consequence of the wealth effect, which is boosting consumption over and above what is normally expected of PCE out of income. Whether in current circumstances it will be possible to offset the increase in demand on the cost side, I think, is the wrong question to ask. That's because it is by no means evident that the current expansion is going to slow at all. The reason is that if productivity is continuing to accelerate and we put that into our econometric model, we are not going to get a slowdown in economic activity. We are going to get motor vehicle sales possibly of 20 million at an annual rate instead of, say, 17 million. We are going to get housing starts of, say, 2 million and not 1.5 million because gross domestic income and gross domestic product--leaving out the discrepancy, as I have indicated previously-have to balance. . The reason I raise this question is that we are seeing a remarkable acceleration in economic activity now, which under our old regime where the supply side is relatively stable would lead us to say that this expansion is getting dramatically out of hand.

So, I would say that the issue is not whether productivity can grow fast enough to keep pace with demand growth. We are dealing with a simultaneously structured economy in which the very forces that are driving productivity — primarily technology — are boosting the income side and the capital assets side, both of which are having an impact on the demand side. I think it is essential for us to recognize that we have this kind of interaction. If we don't, we very well could be looking at a benign expansion on the demand side that is being fostered wholly by increased productivity and wrongly view it as overheating. 
I am not saying that the evidence is completely consistent with the argument I have just made. Even with that argument, we still have a significant wealth effect, so that actual demand growth is in excess of potential supply; but both are rising very rapidly. All I can say is that at this particular stage the number of workers who are seeking jobs is decreasing. As that number shrinks, real compensation per hour obviously will move well ahead of productivity at some point, in which case inflation will take place. So, even under my assumption that the second derivative is positive, all that does is to prevent unit labor costs from rising for a while. But at some point, that process engenders greater growth in real compensation per hour than in productivity, which itself is accelerating, and at the end of the day we end up with acceleration in prices. The difference between the two scenarios is that the time frames are dramatically different. In one case we are looking at acceleration in inflation almost immediately as we get into the year 2000, while the other scenario delays the whole process--perhaps quite significantly. Moreover, it may very well be, as I think a number of us are expecting, that the wealth effect will finally simmer down because of the existence of a bubble that can't persist and that the two effects will converge and there will be no inflationary imbalances.

I submit that we have a very complex set of problems to deal with, and we have to exercise a bit of humility in looking at the models we are employing to reflect reality, as a number of you have said. Because we have used a zero second derivative for productivity in every forecast, we have underestimated real economic growth and overestimated inflation. A lot of you have mentioned that. I submit that we are doing it again. That does not mean it's the wrong thing to do, but I do wish to suggest that there is an alternative assumption. The difference is whether you consider the first derivative to be positive and constant or you wish to add a second derivative that is also positive. I am saying that the most recent trend would argue in favor of the second alternative, which is just an extrapolation of what has been occurring. The question is whether that assumption is valid.

Little discussion followed the Chairman's extended lecture. In effect, though, Greenspan was arguing that rapid productivity growth, via wealth effects, would fuel a boom in housing not seen since the 1970s, and an historic rise in auto sales. From the vantage point of 2011, Greenspan's forecast for housing starts to reach 2 million units and auto sales to reach 20 million units appear rather prescient. Although sales of passenger cars and light trucks peaked at about 18 million units in the first quarter of 2005, housing starts eventually surpassed 2 million units in late 2003 and would hit a peak of nearly 2.3 million units in

January 2006.

For the November 1999 meeting, the staff increased its predicted growth of structural (trend) labor productivity by several tenths, in part due to revisions to the national income accounts data. ${ }^{27}$ Committee members almost uniformly saw robust productivity gains in their districts, and adopted the Chairman's viewpoint. Yet, several members expressed concerns regarding how long the Chairman's second

${ }^{27}$ For discussions of productivity revisions and the national income account revisions, see Anderson and Kliesen (2006). 
derivative of productivity could remain positive before returning to its "traditional" value of zero. In his soliloquy, Chairman Greenspan acknowledged that accelerating productivity creates an "unbalanced" expansion that cannot continue-demand increases due to the induced wealth effect threaten the productivity acceleration itself. Again, the Chairman utilizes a long lecture to persuade the Committee to accept his economic model and "follow his lead." In this discussion, however, the focus begins to turn away the beneficial effects of more rapid productivity growth and toward the corrosive effects of overly rapid, productivity-fueled demand growth [We have edited for length]:

On the productivity side, the data if anything continue to be strongly supportive of increasing rates of productivity gains. . . [T] he escalation of productivity is far more pronounced, in terms of its second derivative so to speak, if we use both the income side measure of output and the household survey measure of hours to make the calculations over the past several years-indeed, going back into the 1980s... And the question is how that should be interpreted.

One thing that is important to interpret is whether accelerating productivity engenders a stable economic system. The answer is, in fact, that it does not, and it's in this regard that accelerating productivity exerts upward pressure on real long-term rates. The reason is that if we get accelerating income-side or supply-side growth and the propensity to consume out of the income engendered from that is unchanged, then arithmetically we end up with demand equal to supply. The unemployment rate does not change. The associated inflation pressures are nonexistent. But there is a problem in the fact that if productivity is accelerating and if it is presumed that the underlying cause of that acceleration will change the long-term outlook for corporate earnings at any existing fixed discount rate, the expectation of higher earnings will engender an increase in stock market wealth. And of necessity if there is a wealth effect-and there is some dispute about that between New York Bank and Board staff--we invariably will get a decline in the propensity to save out of income. So, we end up with the need to satisfy aggregate demand in excess of domestic supply.

The bottom line is that we really do not know how this system works. It's clearly new. The old models just are not working. And the reasons they are not working are essentially that we have a rapidly changing structure whose parameters are very difficult to estimate, and, therefore, we have to depend in part on anecdotal information and in part on some sort of risk evaluation.

The final meeting of 1999, on December 21, contained little analysis not in prior meetings. The wealth effect was prominent in the Chairman's remarks as he argued that it cannot—and hence will notcontinue indefinitely. But few price pressures were noted, and the Committee agreed that a policy action would be unwise on the eve of the millennium.

\section{A NEW MILLENNIUM, A NEW ENEMY}

Table 1 shows a progression of the staff's projections of structural labor productivity growth at selected FOMC meetings from August 1992 to August 2000. For quite some time in the 1990s, estimates 
of structural productivity by the Board staff remained around 1.5 percent. As seen in Figure 2, this was consistent with private-sector forecasters. But as we have documented, Chairman Greenspan vigorously disputed these estimates for quite some time. Over time, though, data revisions began to confirm the Chairman's hypothesis that, first, the data was flawed, and second, the staff's model was giving an inaccurate portrait of underlying productivity growth. This began to change dramatically in 1999 and by the time of the first meeting of 2000, February 1-2, the staff was now estimating structural productivity growth to be 3 percent-nearly double the pace of the 1980s and early 1990s. Projected potential output growth increased to a 4 percent rate over 2000 and 2001, as multifactor productivity increased to near a 1 percent annual rate. A number of members expressed doubts. President Minehan noted that the revised productivity growth is more rapid than almost all other forecasters. Governor Meyer, who by now had become a full-fledged convert to Greenspan's hypothesis, defended the staff's forecast by noting that they more accurately captured the effects of productivity revisions on supply and demand better than most private-sector forecasts. This assertion was based on Chairman Greenspan's “virtuous circle” wherein demand is boosted by wealth effects flowing from the productivity acceleration.

Inflation concerns were widespread. President Moskow cited reservations from his academic advisory council; others cited concerns regarding labor market pressures. Governor Gramlich noted that unit labor costs are near constant, and that the Blue Chip survey forecasts no increase. Governor Meyer, who a few years earlier chided the Chairman as a poster child for the New Economy, again draws on the implications of the virtuous circle for further undesired increases in aggregate demand:

My first observation is that the risks have now become significantly tilted toward higher inflation. That judgment is based on the still more robust growth at the already very high labor utilization rate, by the dissipation or reversal of the favorable relative price shocks that have been restraining inflation, and by some signs of incipient pressure on nominal compensation and inflation. . While there have been consistent upward revisions to trend growth and a growing appreciation of the importance of higher productivity growth in explaining recent macroeconomic experience, the key challenge for monetary policy today derives from the persistent imbalance between the growth in supply and demand.

In his remarks, Chairman Greenspan displays a shift toward the cautions expressed by Governor Meyer: The wealth effect resulting from productivity acceleration, eventually, will cause an unacceptable increase in inflation. In the near-term, he argues, "inflation will stay down because of the acceleration in 
productivity. But, ultimately, if we do not solve the problem of the gap, meaning that if the acceleration in productivity leads to continued expectations of accelerating earnings per share, the only way to eliminate the wealth effect, which has to be eliminated, is for the market rate used by investors to calculate the present value of expected earnings to rise." Yet, he councils caution because "too aggressive" an increase in the federal funds policy target could "crack the [stock] market" and lead to financial instability. He proposes a 25 basis point increase-despite there being no evidence of increasing inflation. It is impossible to know to what extent this action was intended to build consensus on the Committee.

At the March meeting, the staff again increased its estimate of trend productivity by 0.2 percentage points to 3.2 percent, albeit still somewhat less than 2000's published 3-3/4 percent increase (see Table 1). Most members comment that little has changed since the previous meeting. Governor Meyer concurs, raising in his comments the "inflation alarm" louder and clearer than other members, but argues that the Committee should engage in a preemptive tightening action:

While core inflation remains well contained, I agree with the Greenbook forecast that it will soon begin to rise, reflecting the secondary effects of the recent rise in oil prices, the dissipation or possible reversal of various favorable price shocks that restrained inflation earlier, and the effects of very tight labor markets. Monetary policy tightening today would clearly be preemptive and appropriately so. . . Slowing the economy to trend is unlikely to contain the risk of higher inflation. .. We should therefore be especially determined to slow the economy at least to trend quickly and to be aggressively reactive to increases in core inflation.

Director Kohn concurs, while noting that recent further acceleration of productivity will temper inflationary pressures for the near-term. Kohn emphasizes that, if accelerating productivity is increasing the economy's neutral, or "natural," rate of interest, than further increases in the Committee's nominal interest rate target are necessary to forestall further upward pressure on inflation from increased productivity. The "virtuous circle" is reversed! The sheen clearly has faded on the productivity acceleration miracle among the Committee members. In his remarks, Chairman Greenspan reiterates the same points.

Discussion at the May 2000 meeting is similar, with Director Prell noting that the Committee likely has not yet increased rates enough to close the gap between demand and supply growth. Startling is 
Chairman Greenspan's de facto labeling of further productivity acceleration as "Public Enemy Number 1" in the fight for price stability. Productivity accelerations-something that most economists would believe to be overwhelmingly beneficial to the economy — are labeled as weed to be eradicated via rapid interest rate increases. Wisdom? Dismissing the staff's productivity projections, the Chairman recommends a 50 basis point increase in the funds rate target. In part, the Chairman's rationale rests on the arguments made by President Broaddus a year earlier (higher real interest rates are necessary response to a favorable productivity shock):

The reason I am not concerned about moving the rate up quickly at this stage is that I think the evidence indicates that productivity, indeed perhaps underlying GDP, is still accelerating. I recognize that the staff's estimate of productivity growth for the first quarter, based on the latest published figures and adjusted for the defense spending anomaly, is $1-1 / 2$ percent. I don't believe that estimate for a fraction of a second. I don't think it has even a remote possibility of being accurate because of the evidence we are getting on profit margins, which clearly are still opening up at this point. Indeed, using the available data on income and profits, which essentially reflect the unit cost structure of nonfinancial corporations, the productivity growth number that falls out of that system according to staff estimates is a 6 percent annual rate. That number is consistent with our unit cost analyses and our estimates for prices, profits, and wages, granted that the estimate for wages may be a little to the weak side. . . What is remarkable at this stage is not that inflationary forces are picking up. It is that there is so little evidence of a pickup. I think, for example, that the acceleration in wages is unambiguous. . . I think we are in a quite different environment than we have seen in the past. In such environment real long-term interest rates have to rise.

I think what we have is still the beginning, or perhaps we are well into it at this stage, of a significant long-term change in the behavior of the economy. This is not to say that we don't have a cyclical element involved in these growth numbers nor does it mean that higher interest rates, especially real long-term rates, are having no effect. Indeed, the evidence is now beginning to show that the alleged absence of any effect from what we have done to date, or more importantly what the markets have done to date, is a false notion. . There is as yet no compelling evidence that inflationary pressures are easing, I believe it would be a mistake not to stay asymmetric and our press release should reflect such a decision.

Director Stockton notes that inflation remains tame. Although energy prices had boosted personal consumption expenditures (PCE), growth of core PCE [omitting food and energy] was projected to fall back to a 2 percent rate in 2001 . Nevertheless, he recommends an highly aggressive 75 basis point increase in the federal funds policy target to forestall possible inflation. As seen in Figure 6, the intended federal funds target was now at 6.5 percent, where it would remain until January 2001. 
The momentum toward tightening — to fight an inflation not yet in evidence-continues at the June meeting. In many respects, the FOMC by this meeting has adopted inflation-forecast targeting — but how accurate are the forecasts? Governor Gramlich, in comments that in two years time will seem near clairvoyant, cautions against moving policy too quickly and too far on the basis of highly uncertain forecasts:

Until now the real economy has been rocketing ahead at a seemingly unsustainable rate and there was at least a whiff in the air that underlying inflation was picking up. Now real growth has slowed, quite quickly in fact, and the signs of acceleration in inflation do not look so strong either. .. It is at least possible that the Fed has already done enough tightening and that we can stand back and examine our work. There are grounds for thinking that we have done enough already. If the long-run core inflation rate is about 2 percent and the long-run real interest rate is around 4 percent-which can be read from either the TIP market or inflation-corrected nominal interest rates - the nominal federal funds rate should be at least 6 percent for a balanced economy. Throw in 50 basis points for leaning against the wind or adjusting for the balance of risks and we are at the present funds rate.

Let me make one further comment on the hard landing scenario. While the risk of recession was the last thing on everybody's mind last month when the economy was rocketing ahead, the sharp drop in real growth at least raises this issue. Given the strength of the present investment boom, I am inclined to downplay any risk of recession. But the Committee should be mindful of the risk of overshooting. Policy should be preemptive on the down side as well as the up side. Putting all this together, it is possible that the Fed has already done enough, that the funds rate is already high enough to stabilize the economy. But I emphasize the word possible because there is still significant risk that the NAIRU could be in excess of 5 percent and then inflation could begin to heat up or, in Bill Poole's terms, that the Fed won't be perceived as being tough enough on inflation. For now at least, I'm fairly comfortable reverting to our previous watchful waiting mode, giving strong signals that we still think the balance of risks is on the up side and that we are prepared to take appropriate action if the data become disquieting.

The Chairman's remarks, somewhat briefer than often is the case, reiterate his position from the prior meeting, that further productivity acceleration represents a clear and present danger to price stability.

Nothing is gained by repeating them here.

At the August 2000 meeting, with the economy at the tail end of the extraordinarily long 1991-2000 expansion, the staff once again increased its projection of structural productivity growth. This was largely because of newly-revised incoming data. Board research director David Stockton noted a sea-change in the staff view, however. Previously, productivity accelerations were seen as inducing demand increases in excess of supply gains. Now, further consumer spending gains were viewed as unlikely, although business investment remained robust. This turning point in the staff projections is important: 
In contrast to the signs of slowing in household spending, business outlays for capital equipment have continued to surge ahead. One of the most notable aspects of the recent annual revision to the national accounts was that the investment boom of recent years is now estimated to have been even stronger than previously thought. Moreover, there are few signs, if any, that higher real longterm interest rates have put an appreciable dent in the demand for equipment and software. It just doesn't look like this boom is about to dissipate any time soon. . .

Taken together, these observations motivated our upward revisions to the growth of structural productivity and potential output. Indeed, given both the mounting contribution from capital deepening implied by our investment forecast and some further improvement in the growth of multifactor productivity, we are projecting a modest ongoing acceleration of structural productivity--3-1/2 percent this year and 3-3/4 percent in 2001, up about $1 / 2$ percentage point from our last forecast. The revision to structural productivity not only affects potential GDP, it also has important implications for the demand side of our forecast. In particular, it boosts the growth of real incomes and spending and is the chief reason that we have adjusted up our real GDP growth forecast by a half percentage point in 2001 to 4 percent. This outcome might seem somewhat surprising in light of many of the simulations we have shown you in recent years. In those simulations, faster trend productivity growth typically caused growth in demand to outstrip that of the productivity-enhanced growth of supply, at least for a time. As you will recall, an important channel for that effect came through the influence of faster productivity growth on asset values and, consequently, on consumption and investment. But our interpretation of recent events is that while we hapless economists have been only slowly marking up our forecasts for productivity growth, the markets and private-sector agents had already been anticipating this improvement. Thus, we are not looking for any additional increment to spending from a further productivity-driven rise in the stock market.

The slowing expenditures of late 2000 become a rout during 2001 - the previously undesired further strength in aggregate demand would be as welcome as the prodigal son. Did inflation forecast targeting fail the FOMC? Did the FOMC fail inflation forecast targeting? Or did an economic shock bedevil the forecasts?

The year 2001 begins with a January $3^{\text {rd }}$ FOMC conference call, a reaction to perceived weak incoming economic data regarding employment, corporate earnings, retail sales (including motor vehicles), consumer confidence, and housing markets. In discussion, it becomes apparent that members have not changed their hawkish views regarding trend, or "structural," productivity growth, and regard recent weakness in productivity growth as cyclical. Chairman Greenspan notes: "I think it is important to indicate in our press statement that there is little evidence to date of any deterioration in the long-term advances in technology and the related expansion in productivity." His desire is quickly supported by other Committee members.

Optimism regarding productivity growth continued at the January 30-31 meeting. Key was the staff's view that multifactor productivity was "still growing rapidly." Moreover, the staff held the view 
that strong growth of structural productivity was being "reflected in a strong expansion of permanent income, and, after the economy passes through the current inventory correction, in actual income as well." The staff" "subdued" inflation forecast was also attributed to the faster growth of structural productivity. Chairman Greenspan remained convinced not only that the economy was in the midst of a massive structural change, but that monetary policymakers would have to face the prospect of altering their response to economic developments:

To me the evidence strongly suggests that we are in an advanced high-tech and just-in-time inventory type of economic system, including the capital goods markets where adjustments happen far faster because information is so much more readily available. If that is the case, since we are dealing with mood swings that are rooted in an unchanging human nature, then I think it follows that monetary policy must also compress itself into a narrower timeframe. That means we have to move faster, sooner, quicker, and complete the operation in a shorter period of time."

Meetings during the balance of the year raised few new issues. Eventually, the recession of 2001 gave way to the so-called jobless recovery of 2002-2003. At the January 29-30, 2002, with the intended federal funds target rate 1.75 percent, the meeting opened with a discussion of the zero-bound problem for monetary policy. ${ }^{28}$ The FOMC would eventually lower its target rate to 1 percent at the June 2003 meeting and hold at the level for a year. In part, the Committee's decision reflected an unwelcome fall in inflation. But because that episode of super-easy monetary policy, arguably, had a profound influence on the macroeconomy and monetary policy discussions for many years to come. However, that story is best left to another paper.

\section{CONCLUSIONS}

Productivity's acceleration has played a major role in monetary policymaking during the last decade, and a significant part of the policy debate concerned the quality of incoming data. Accurate, timely data are essential for activist monetary policymaking. The FOMC transcripts from 1996 and 1997

\footnotetext{
28 The zero bound problem arises when a central bank, working with an overnight interest rate as its single policy instrument, finds that the desired setting for that rate is below zero. Nominal interest rates cannot be less than zero (absent a subsidy or partial forgiveness of a debt). If the policy rate is at the zero bound and inflation is falling, then the real policy rate will be increasing; if, in turn, this further attenuates economic activity such that inflation falls further (or becomes negative), a cumulative process might be launched that drives the economy into an extended downward spiral.
} 
suggest that Chairman Greenspan placed little confidence in aggregate real GDP as an indicator of the direction of the economy. Rather, his focus was on a broad array of individual-industry data. In particular, he focused on productivity growth in manufacturing and the broader nonfinancial corporate sector. One danger in such a disaggregate approach is that many industries primarily produce intermediate products that do not appear directly in GDP. ${ }^{29}$ Policymakers risk significant errors if they respond too rapidly to incoming data that later revise significantly. ${ }^{30}$

The FOMC's experience with productivity growth teaches several lessons. First, anecdotal evidence can be extremely valuable in forming perceptions of underlying data not readily apparent in the published data—an observation comfortable to business economists but frightening to some academics lacking business experience. Second, disaggregate data can also be informative, sometimes before changes are apparent in aggregate published data, despite the typical emphasis of policy being only aggregate variables such as real GDP. Third, if policymakers have valid reasons for questioning the reliability of the published data, then model-based forecasts should be used cautiously. These aspects of policymaking, which undergird much of its uncertainty, implies that monetary policy is an exercise in risk management. Alan Greenspan was a firm advocated of this approach. However, success in risk management often requires some gambling instincts—and like most gambling, losses might be incurred. During the 1990s, the FOMC's gambling paid handsome rewards. Policymaking by Committee is difficult, and the skill of a chairman to bring consensus cannot be overvalued. Finally, inflation forecast targeting is not easily implemented. At times during the 1990s and early 2000s, inflation forecast targeting with misspecified models appeared to lead the FOMC astray.

\footnotetext{
29 This point is made clearly by Triplett (2002).

${ }^{30}$ In the models of Svensson and Woodford (2003, 2004), optimal response to imperfect observation of output (and productivity) depends on the noise in the system. The optimal response to the optimal estimate of output displays certainty equivalence — but what is to be done when different policymakers have different estimates of potential output?
} 


\section{References}

Abrams, Burton A. (2006). "How Richard Nixon Pressured Arthur Burns: Evidence from the Nixon Tapes," Journal of Economic Perspectives, 20(4), pp. 177-88.

Anderson, Richard G., and Kevin L. Kliesen (2010). "FOMC Learning and Productivity Growth (19852003): A Reading of the Record," Federal Reserve Bank of St. Louis Review, March/April, 92(2), pp. 129-53.

(2006). "The 1990s Acceleration in Labor Productivity: Causes and Measurement," Federal Reserve Bank of St. Louis Review, May/June, 88(3), pp. 181-202.

Armstrong, Philip, Harchaoui, Tarek M., Jackson, Chris, and Tarkhani, Faouzi (2002). "A Comparison of Canada-U.S. Economic Growth in the Information Age," Research Paper, 11F0027MIE No. 001, Statistics Canada, March.

Basu, Susanto, John G. Fernald, Nicholas Oulton, and Sylaja Srinivasas. (2003). "The Case of the Missing Productivity Growth, Or Does Information Technology Explain Why Productivity Accelereated in the United States But Not in the United Kingdon?" NBER Macroeconomics Annual 2003, Mark Gertler and Kenneth Rogoff, eds., The MIT Press.

Bremner, Robert P. (2004). Chairman of the Fed: William McChesney Martin Jr. and the Creation of the Modern American Financial System, Yale University Press.

Blinder, Alan, and Ricardo Reis (2005). "Understanding the Greenspan Standard," in The Greenspan Era: Lessons for the Future, Federal Reserve Bank of Kansas City, pp. 11-96.

Brynjolfsson, Erik and Lorin Hitt (1996). "Paradox Lost? Firm-Level Evidence on the Returns to Information Systems Spending," Management Science, INFORMS, April, Vol. 42(4), pp. 541-58.

(2003). "Computing Productivity: Firm-Level Evidence," The Review of Economics and Statistics, November, Vol. 85(4), pp. 793-808.

Colecchia, Alessandra and Paul Schreyer (2002). "The Contribution of Information and Communications Technologies to Economic Growth in Nine Countries," OECD Economic Studies No. 34, pp. 153-171, Organisation for Economic Cooperation and Development, Paris.

Corrado, Carol and Lawrence Slifman (1999). "Decomposition of Productivity and Unit Costs," American Economic Review, May, pp. 328-32.

David, Paul A. (1989). "The Dynamo and the Computer: An Historical Perspective on the Modern Productivity Paradox," American Economic Review, May, pp. 355-61.

Dynan, Karen E. and Dean M. Maki (2001). "Does Stock Market Wealth Matter for Consumption?" FEDS working paper 2001-23. Board of Governors of the Federal Reserve System, Washington, D.C.

Dewan, Sanjeev and Min, C.K. (1997). "The Substitution of Information Technology for Other Factors of Production: A Firm-Level Analysis," Management Science, Vol. 43(12), pp. 1660-75. 
Edge, Rochelle M., Laubach, Thomas and Williams, John C (2004). "Learning and Shifts in Long-Run Productivity Growth," Working Paper 2004-21, Board of Governors of the Federal Reserve System, April.

Gordon, Robert J. (2000). "Does the 'New Economy' Measure up to the Great Inventions of the Past?" Journal of Economic Perspectives (Fall 2000), pp. 49-74.

Gordon, Robert J. (2003). "Exploding Productivity Growth: Context, Causes and Implications," Brookings Papers on Economic Activity, No. 2, pp. 207-298.

Gramlich, Edward M. (2002). "Consumption and the Wealth Effect: The United States and the United Kingdom," Remarks Before the International Bond Congress, London, United Kingdom, February 20.

Greenspan, Alan (2004). "Risk and Uncertainty in Monetary Policy," remarks at the meetings of the American Economic Association, San Diego, CA, January 3. . (2007). “The Age of Turbulence: Adventures in a New World,” New York: Penguin Group.

Gurbaxani, Vijay, Nigel Melville and Kenneth Kraemer (1998). "Disaggregating the Return on Investment to IT Capital," Center for Research on Information Technology and Organizations, University of California, Irvine, September 11.

Jorgenson, Dale W., Mun Ho, and Kevin J. Stiroh (2002). "Projecting Productivity Growth: Lessons from the U.S. Growth Resurgence." Federal Reserve Bank of Atlanta Economic Review, Quarter Three, 87(3): $1-13$.

Kouparitsas, Michael A. (2005). "Is There Evidence of the New Economy in U.S. GDP Data?" Economic Perspectives, Federal Reserve Bank of Chicago, First Quarter, pp. 12-29.

Kozicki, Sharon (1997). "The Productivity Growth Slowdown: Diverging Trends in the Manufacturing and Services Sectors," Economic Review, Federal Reserve Bank of Kansas City, First Quarter, pp. 31-46.

Melzer, Allan H. (2003). A History of the Federal Reserve, Volume 1: 1913-1951. University of Chicago Press.

Meyer, Laurence H. (2003). A Term at the Fed: The People and Policies of the World's Most Powerful Institution. HarperCollins, New York, NY.

Melville, Nigel, Kenneth Kraemer and Vijay Gurbaxani (2004). "Information Technology and Organizational Performance: An Integrative Model of IT Business Value," MIS Quarterly, June, Vol. 28(2), pp. 283-322.

Orphanides, Athanasios and Simon Van Norden. (2002). "The Unreliability of Output Gap Estimates in Real Time," Review of Economics and Statistics, 84(4), November, pp. 569-583.

Pilat, Dirk and Frank Lee (2001). "Productivity growth in ICT-producing and ICT-using industries: A source of growth differentials in the OECD?" STI Working Paper 2001/4, Organisation for Economic Cooperation and Development, Paris. 
Ramirez, Ronald V. and Nigel Melville (1998). "Information Technology in Large Corporations: Ten Years of Evolution," Center for Research on Information Technology and Organizations, University of California, Irvine.

Romer, Christina D. and David H. Romer (2002). "The Evolution of Economic Understanding and Postwar Stabilization Policy," in Rethinking Stabilization Policy, Federal Reserve Bank of Kansas City.

(2008). “The FOMC versus the Staff: Where Can Monetary Policymakers Add Value?"

American Economic Review, 98(2), pp. 230-5.

Sargent, Thomas (2002). "Commentary: The Evolution of Economic Understanding and Postwar Stabilization Policy.” In Rethinking Stabilization Policy. Federal Reserve Bank of Kansas City.

37. . (2008). “Evolution and Intelligent Design,” American Economic Review. 98(1). March. pp. 5-

Svensson, Lars E. O. and Michael Woodford. (2003). "Indicator Variables for Optimal Policy," Journal of Monetary Economics, Volume 50, pp. 691-720.

. (2004) "Indicator Variables for Optimal Policy under Asymmetric Information," Journal of Economic Dynamics and Control, Volume 28, Issue 4, January, pp. 661-690.

Tallman, Ellis W. (2003). "Monetary Policy and Learning: Some Implications for Policy and Research," Federal Reserve Bank of Atlanta Economic Review, Third Quarter, pp. 1-9.

Thornton, Daniel L. (2006). "When Did the FOMC Begin Targeting the Federal Funds Rate? What the Verbatim Transcripts Tell Us," Journal of Money, Credit, and Banking, 38(8), December, pp. 2039-71.

Triplett, Jack E. (2002). "The Mismeasurement Hypothesis and the Productivity Slowdown.” In Nathalie Greenan, Yannick L'Horty and Jacque Mairesse, eds. Productivity, Inequality and the Digital Economy: A Transatlantic Perspective. MIT Press, Cambridge, MA.

Woodward, Bob (2000). Maestro: Greenspan's Fed and the American Boom, Simon and Shuster, New York, NY.

Wynne, Mark A. (2002). "How Did the Emergence of the New Economy Affect the Conduct of Monetary Policy in the US in the 1990s?" Paper prepared for the International Association for Official Statistics Conference on the New Economy, London, UK, August 27-29. 
Table 1

FOMC Staff Estimates of Structural (Trend)

Labor Productivity Growth

(Estimates reported in the transcripts)

FOMC

Meeting Productivity

Date Estimate

Aug. $1992 \quad 1.00$

May $1992 \quad 1.50$

May $1999 \quad 1.75$

June $1999 \quad 2.25$

Nov. 1999* $\quad 2.70$

Feb. $2000 \quad 3.00$

Aug. $2000 \quad 3.75$

*Average of 1998-99 and 2000-01 estimates reported in the Nov. 1999 Greenbook, Part 1. 
Figure 1: Growth of Labor Productivity

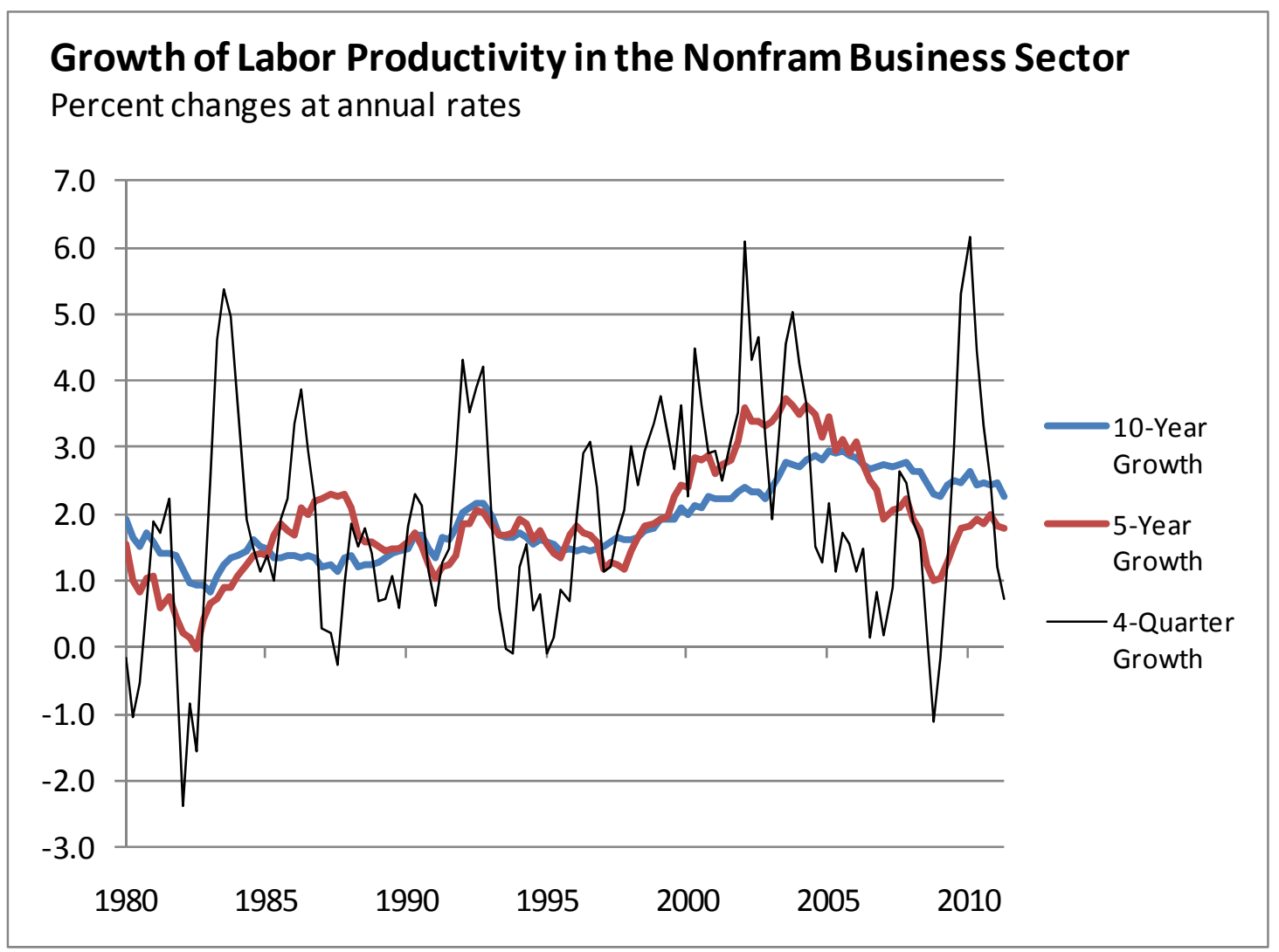


Figure 2: Long-Term Expectations for Output and Productivity Growth

\section{Long-Term Expectations for Growth in Output and Productivity}

\section{Percent changes}

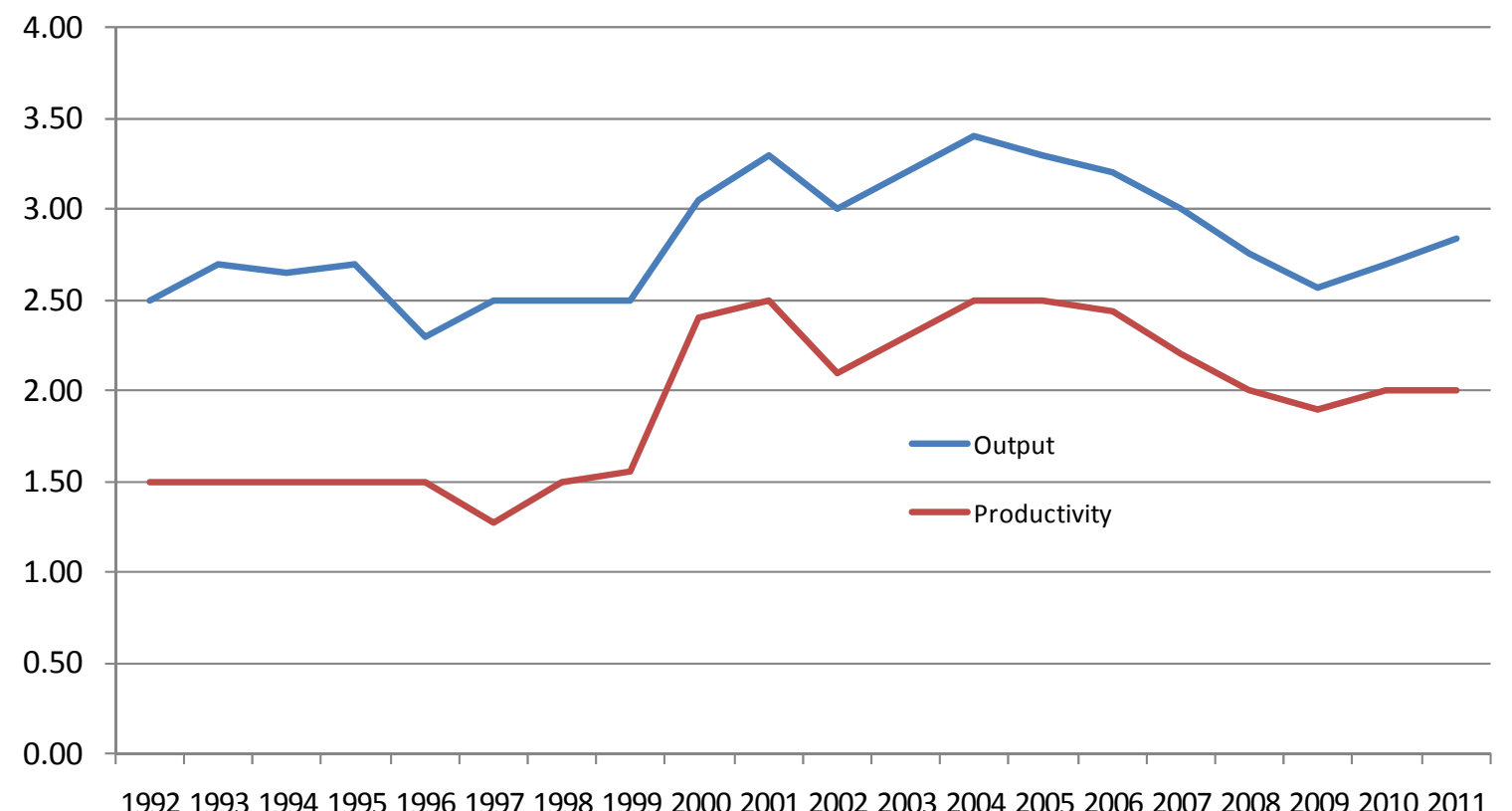

SOURCE: Federal Reserve Bank of Philadelphia 
Figure 3: Estimates of $\mathrm{R}^{*}, 1990-2004$

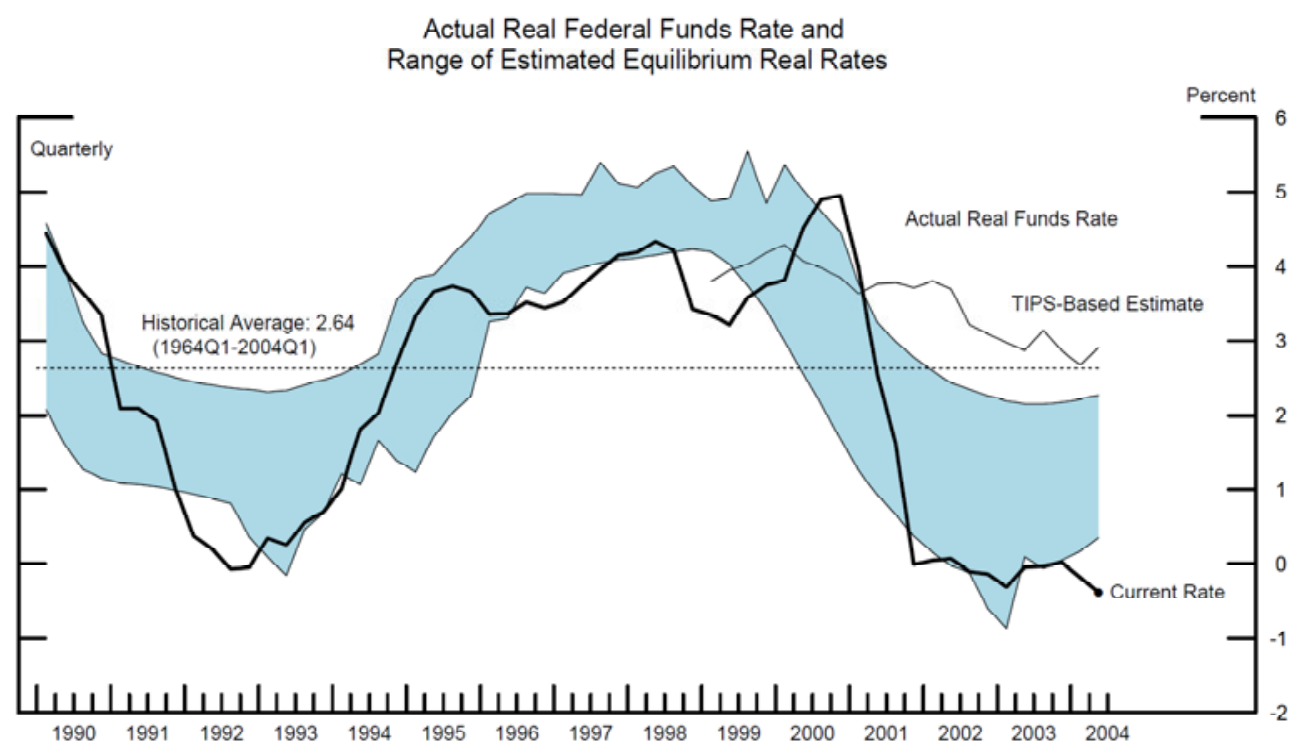

Note: The shaded range represents the maximum and the minimum values each quarter of four estimates of the equilibrium real federal funds rate based on a statistical filter and the FRB/US model. Real federal funds rates employ a four-quarter moving average of core PCE inflation as a proxy for inflation expectations, with the staff projection used for $2004 \mathrm{Q} 2$.

SOURCE: FOMC Bluebook, June 29-30, 2004 
Figure 4: Multifactor Productivity and Prices of Computers and Peripherals

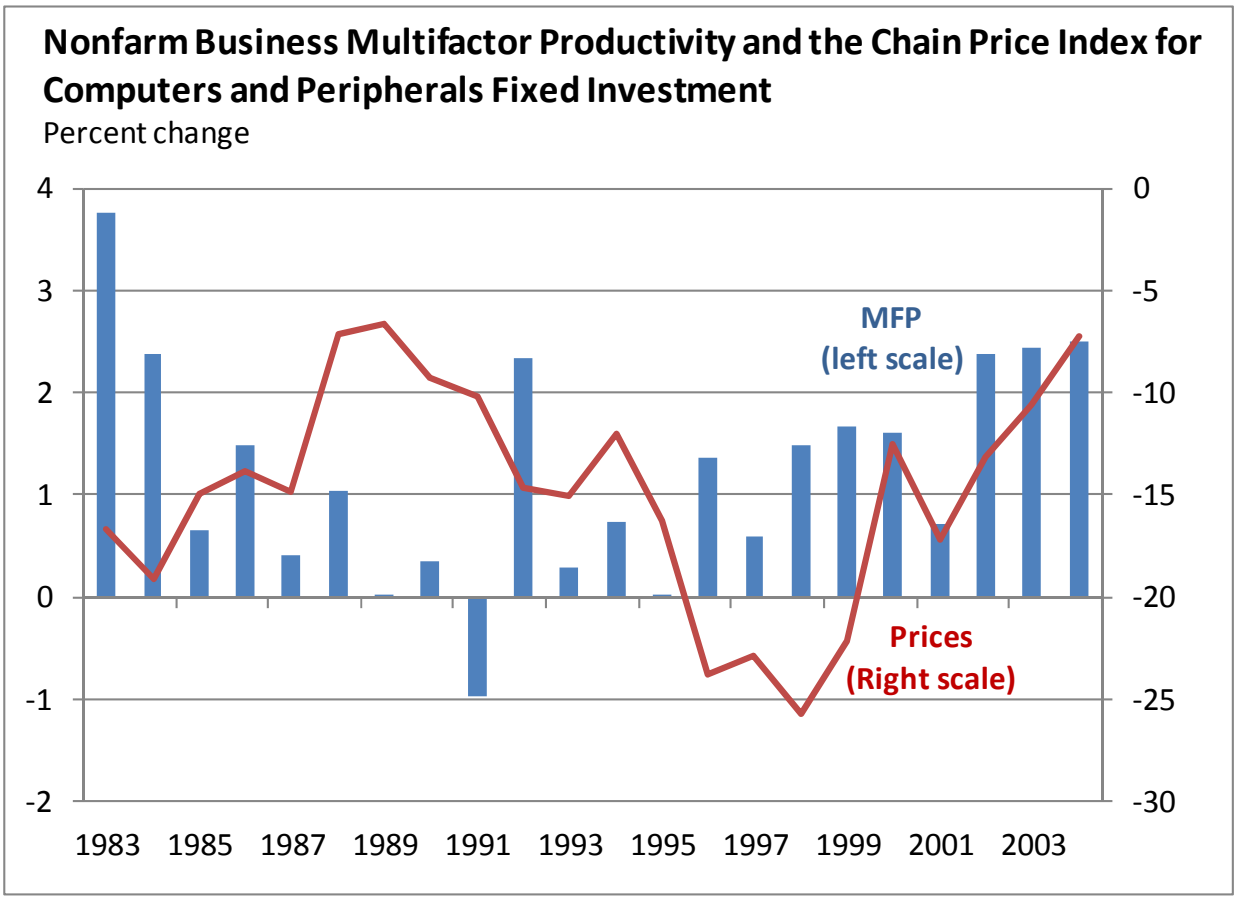


Figure 5: Inflation Forecast Errors

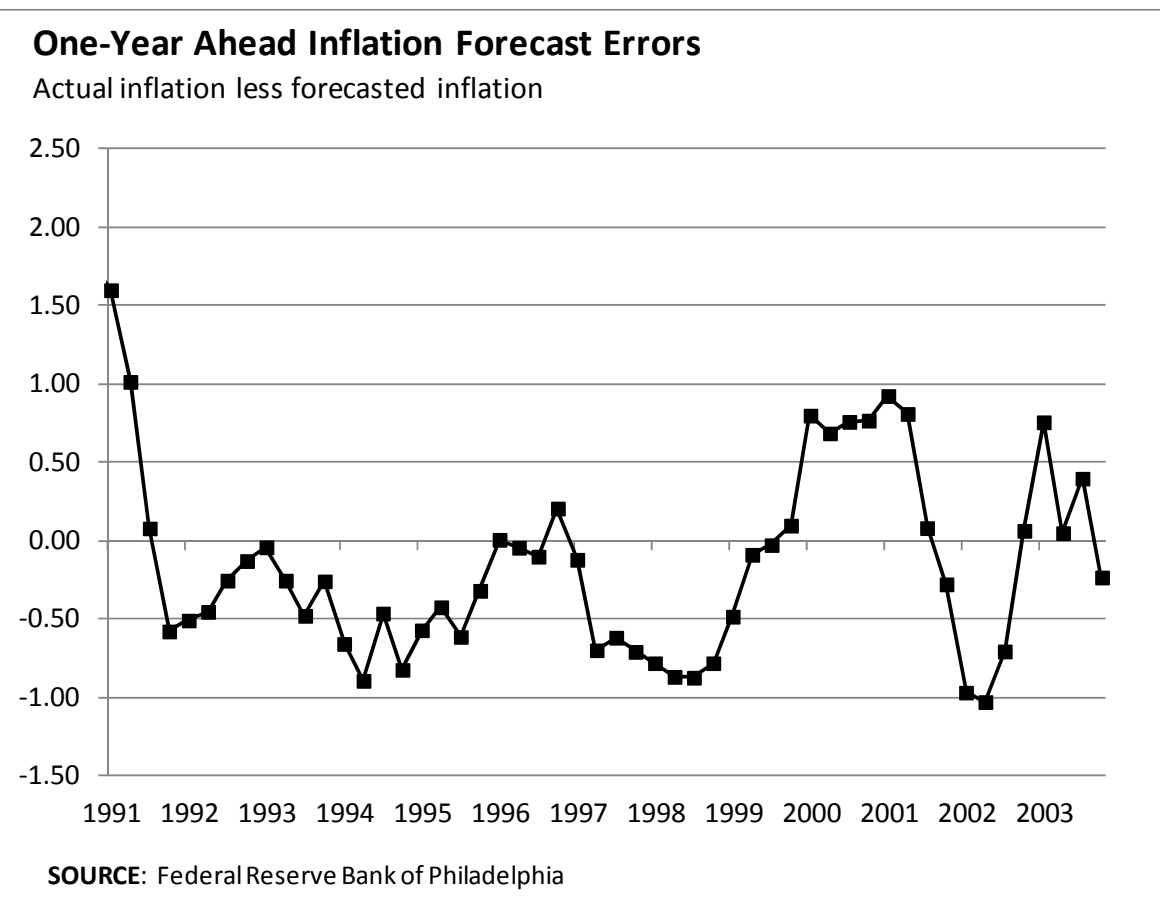


Figure 6: The FOMC's Intended Federal Funds Target Rate

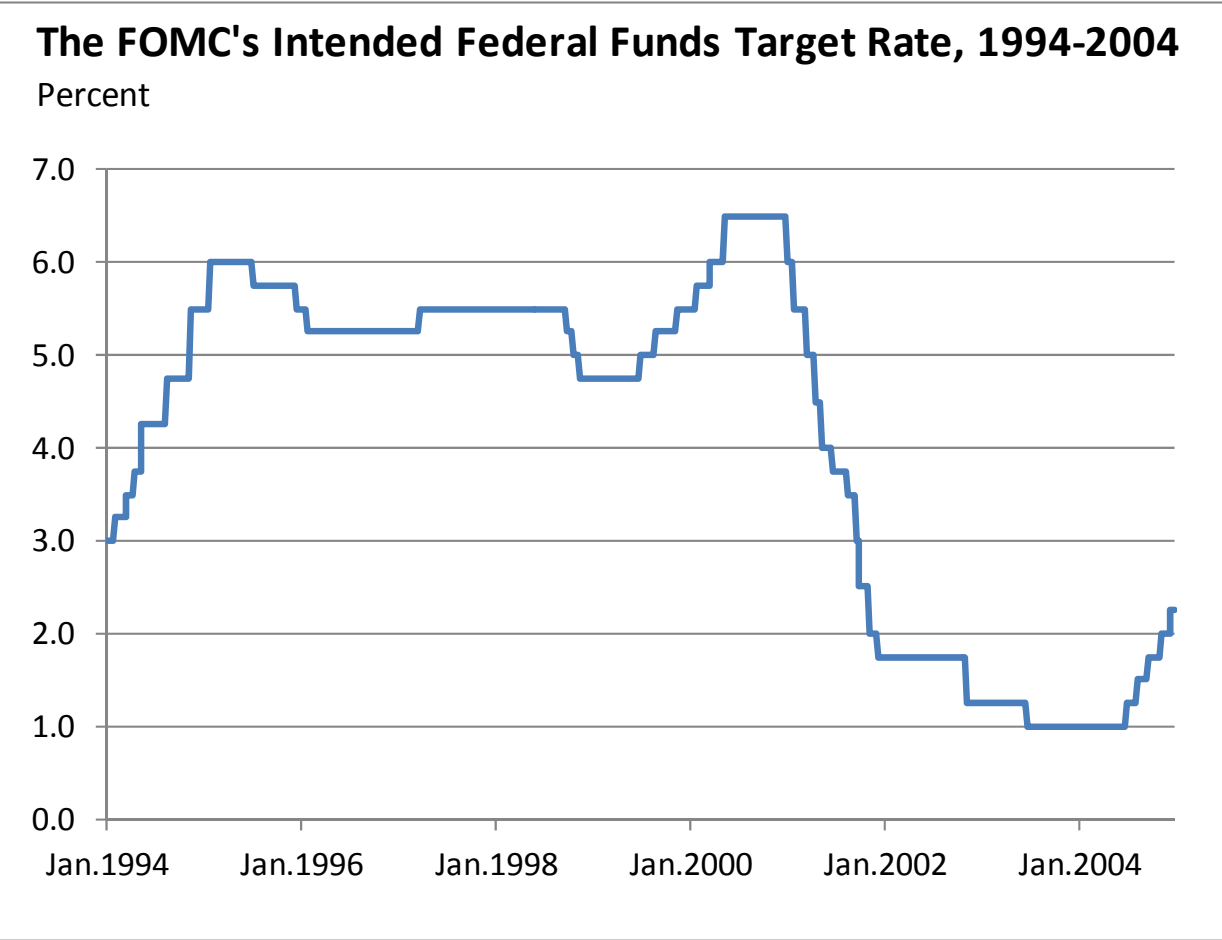

